\title{
Targeting DNA methylation with small molecules:
}

\section{What's next?}

Alexandre Erdmann, Ludovic Halby, Jacques Fahy, Paola B Arimondo*

CNRS-Pierre Fabre USR3388 ETaC, Epigenetic Targeting of Cancer, CRDFP 3 avenue H. Curien, 31035 Toulouse cedex 01, France

* to whom correspondence should be addressed: paola.arimondo@etac.cnrs.fr

KEYWORDS. DNA methylation, drug design, inhibitors, perspectives.

ABSTRACT. DNA methylation is a mammalian epigenetic mark that is involved in defining where and when genes are expressed, both in normal cells and in the context of diseases. Like other epigenetic marks, it is reversible and can be modulated by chemical agents. Because it plays an important role in cancer by silencing certain genes, such as tumor suppressor genes, and by reactivating other regions, such as repeated elements, it is a promising therapeutic target. Two compounds are already approved to treat hematological cancers. Many efforts have been carried out to discover new molecules that are able to efficiently inhibit DNA methylation in cancer cells. We will briefly overview the foremost of these efforts by focusing on what we have learned to this point on non-nucleoside inhibitors and on what we consider to be the features of an ideal inhibitor. 


\section{INTRODUCTION}

Epigenetic modifications play an essential role in the establishment and regulation of differentiation programs that define when and where genes and their products are expressed..,2 Although these changes do not modify the DNA sequence, they regulate gene expression in response to environmental factors by altering the DNA methylation patterns of genes, expression profiles of microRNAs, post-translational modifications of histones and nucleosome positioning. ${ }^{3}$ Epigenetic regulation plays a central role in all biological processes. It is also involved in many diseases, including cancer. ${ }^{4,5,6,7}$ In particular, aberrant epigenetic patterns are clearly implicated in tumor formation and maintenance. Epigenetic modifications have a therapeutic advantage in that they are reversible. Over the last decade, a growing number of molecules ("epidrugs") targeting epigenetic mechanisms (DNA methylation, histone deacetylation, methylation and demethylation, histone readers) have been developed to treat cancer. $8,9,10,11,12,13$

The main epigenetic factors are histone dynamics (i.e., position, composition and chemical modifications of the nucleosomes) and DNA methylation. ${ }^{1}$ In humans, DNA methylation is the most stable epigenetic mark; ${ }^{14}$ it occurs at position 5 of cytosine, predominantly in a $\mathrm{CpG}$ dinucleotide context, and it is catalyzed by C5-DNA methyltransferases (DNMTs), using $S$ adenosyl-L-methionine (SAM) as a methyl group donor. ${ }^{15}$ Two families of DNMT have been identified that methylate DNA: (1) DNMT1, which is responsible for DNA methylation maintenance by methylating newly synthesized DNA strands; (2) DNMT3A and DNMT3B, which are responsible for de novo DNA methylation. It was later shown that DNMT1 can also participate in de novo methylation and that DNMT3A/B can methylate hemimethylated DNA. ${ }^{16}$ DNMT3L is a co-activator, and it is involved in crosstalk with chromatin actors. ${ }^{17}$ The $\mathrm{CpG}$ dinucleotides are not distributed arbitrarily in the human genome. Approximately $70-80 \%$ of all CpG dinucleotides 
are methylated and occur in non-transcribed, repetitive DNA regions, such as retroelements and CpG-rich satellites. $\mathrm{CpGs}$ are clustered in regions called $\mathrm{CpG}$ islands. $\mathrm{CpG}$ islands are typically 0.2-2 kb long and are located in the proximal promoter of more than half of all human genes. ${ }^{18} \mathrm{In}$ normal tissues, these regions are commonly non-methylated. ${ }^{19,20,21}$ If promoter $\mathrm{CpG}$ islands are methylated, the corresponding gene is repressed because of poor recognition by transcription factors and the recruitment of proteins involved in chromatin remodeling, such as methyl-binding proteins MDB. ${ }^{22}$ The failure to maintain DNA methylation and the establishment of aberrant DNA methylation patterns are associated with the under- or over-expression of certain proteins and noncoding RNAs, ultimately leading to cancer. ${ }^{23}$ In cancer, several specific genes are inactivated by promoter methylation within $\mathrm{CpG}$ islands. It is the case for example for tumor suppressor genes $\left(P 16^{I N K 4 a}, P 14^{A R F}, R b\right)$ and DNA damage repair genes $(h M L H 1, M G M T) .{ }^{5} \mathrm{CpG}$ island methylation patterns are associated with a poor outcome in multiple malignancies. In parallel, a global hypomethylation pattern is observed in cancers with consequent genomic instability and chromosomal aberrations. DNA methylation is thus also used as a biomarker for diagnosis and prognosis: methylation of GST-Pi is used to detect prostate cancer (Veridex test by LabCorp), MGMT methylation in glioblastoma patients is predictive of the response to temozolomide, and the presence of methylated SEPT9 in plasma is noted in the diagnosis of colon cancer (ColoVantage by Quest Diagnostics). The expression of DNMT1, DNMT3B or DNMT3A is increased in various tumors, including prostate, hepatocarcinoma, colorectal or breast cancers. Therefore, DNMTs represent attractive therapeutic targets..$^{24,25}$ In the last decade, several DNMT inhibitors (DNMTi) have been proposed to treat cancers. To date, two inhibitors, 1 (5-azacytidine, azacitidine, 5azaC, Vidaza $\left.{ }^{\circledR}\right)^{24}$ and 2 (5-aza-2'-deoxycytidine, decitabine, 5azadC, Dacogen $\left.{ }^{\mathrm{TM}}\right),{ }^{24}$ have been approved by the FDA (U.S. Food and Drug Administration) and EMA (European 
Medicines Agency) against myelodysplastic syndrome (MDS), acute myeloid leukemia (AML) and chronic myelomonocytic leukemia (CMML). Recently, the combination of a low-dose of $\mathbf{1}$ and a benzamide histone deactetylase inhibitor (HDACi), entinostat, afforded promising results in non-small cell lung cancer patients. ${ }^{26}$ In addition, recent clinical results suggest that demethylating agents can reprogram cancer cells to overcome chemoresistance, resensitizing them to chemotherapy, as has been observed with chemoresistant diffuse large B-cell lymphomas reprogrammed by $\mathbf{2}$ to be sensitive to standard chemotherapy. ${ }^{27}$ Together with the HDACi, the two DNMTis are the only epidrugs that have been approved to date. However, these drugs are not selective for various DNMTs, and they are chemically unstable and non-specific. Therefore, there is a real need to identify novel, more specific and selective inhibitors.

\section{DISCUSSION}

\section{1/ Update on the identified inhibitors.}

DNMT inhibitors can be divided into two families: nucleoside analogs (Figure 1) and nonnucleoside compounds (Figure 2).

Nucleoside analogs. Particularly active are the nucleoside analogs, such as $\mathbf{1}$ and $\mathbf{2}$ (Figure 1A), which, once incorporated into DNA in place of deoxycytidine, covalently block DNMTs on position C6 of the nucleotide (Figure 1B).$^{28,29,30,31}$ Despite their high efficiency, their incorporation into DNA can lead to undesired side effects such as dose-limiting neutropenia. ${ }^{32}$ Also their poor bioavailability and chemical and/or metabolic instability in physiologic media limit their use:8,33 under physiological temperature and $\mathrm{pH}$ conditions, $\mathbf{2}$ is degraded into multiple products resulting from hydrolytic opening of the triazine ring, deformylation and anomerization. ${ }^{19}$ Plasmatic halflife for $\mathbf{1}$ following subcutaneous (SC) administration is as short as 41 minutes $^{34}$, and 10 to 35 
minutes for infusion of $\mathbf{2}$, depending on the administration schedule and the analytical method used. ${ }^{35}$ Moreover, $\mathbf{3}$ (zebularine) was designed to reduce the problems of $\mathbf{1}$ and $\mathbf{2}$ since it is a very stable inhibitor with minimal cytotoxicity in vitro and in vivo. ${ }^{36}$ However, the high concentrations of 3 necessary to obtain a level of demethylation in cells ${ }^{37}$ similar to that of other nucleosidic analogues hindered its clinics development. This explains why we and others ${ }^{38,39}$ showed that $\mathbf{3}$ does not form an irreversible covalent complex with DNMT, in contrast to $\mathbf{1}$ and $\mathbf{2}$, but a reversible complex with slow dissociation kinetics. Another strategy was developed in order to improve stability and bioavailability by synthetizing pro-drugs of $\mathbf{1}$ or $\mathbf{2}$. The most promising today is the CpG dinucleotide analog 4 (S110 then SGI-110, Figure 1A), an efficient pro-drug of $2 .{ }^{40}$ The main improvement consists of its resistance to cytidine deaminase (CDA), an enzyme responsible for the metabolic transformation of cytosine to uracil, resulting in the inactivation of $\mathbf{1}$ and $\mathbf{2}$. Compound $\mathbf{4}$ exhibits an aqueous solubility and cytotoxicity comparable to 2 together with improved cell penetration. In vivo DNA demethylation and tumor growth inhibition in human xenograft was demonstrated for $\mathbf{4}$ compared to $\mathbf{2} .{ }^{41}$ Currently $\mathbf{4}$ is undergoing phase II clinical evaluation for MDS, AML, and ovarian and liver cancers (www.clinicaltrials.gov, latest update August 2014).

Oral formulations of both $\mathbf{1}$ and of $\mathbf{2}$ are also under clinical investigation, alone or in combination, in hematologic and solid tumors. More interestingly, oral $\mathbf{1}$ was shown to be bioavailable and active in a Phase I study in MDS and CML. ${ }^{42}$ Indeed, hypomethylating agents are administrated repeatedly even daily for long cycles and thus oral forms are a great improvement for the comfort of the patient. Oral $\mathbf{1}$ is being developed by Celgene Corporation under the code number CC-486, and a detailed investigation of its pharmacokinetic parameters has recently been published. Despite high inter- and intra-patient variability, 1 is rapidly absorbed and the dose of $300 \mathrm{mg}$ daily for 2 or 
3 weeks has been proposed for further studies. ${ }^{43}$ Another strategy to improve the activity of cytosine derivatives consists in combining them with CDA inhibitors such as 5 (tetrahydrouridine, THU) ${ }^{44}$ Efficacy has been demonstrated for $\mathbf{1}$ in preclinical mouse models but a lack of efficacy of THU was observed in higher species due to its poor bioavailability. Therefore, $\mathbf{6 b}$ (fluorinated THU derivatives) were designed and synthesized, exhibiting improved overall pharmacological and pharmacokinetic profile in monkeys compared to THU. ${ }^{44}$ Among these new compounds, E7727 (the exact chemical structure is not yet disclosed) was selected for Phase I-II clinical evaluation in combination with 2 [NCT02103478, lastest update July 2014]. The $2^{\text {nd }}$ generation of nucleoside analogs is certainly the next generation of hypomethylated agents. However, these chemical agents suffer from lack of specificity vis-à-vis the DNMTs because of their mechanism of action.$^{45}$ Therefore, during the last 10 years, a lot of effort has been concentrated on developing non-nucleoside inhibitors, the $3^{\text {rd }}$ and $4^{\text {th }}$ generation of DNMT inhibitors.

The non-nucleoside analogs. Several non-nucleoside analogs targeting the catalytic activity of these enzymes have been described: 7 (SGI-1027) ${ }^{46}, 8$ (procainamide) ${ }^{47}, \mathbf{9}$ (tea polyphenol (-)-

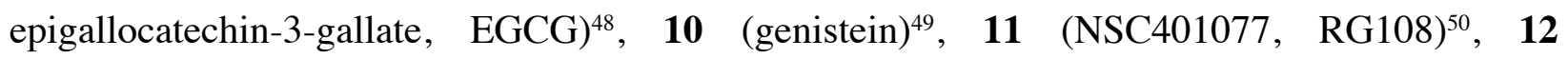
(hydralazine) $)^{51}$ among others (Figure 2). Although the first generation of compounds lacks specificity for DNMTs compared with other enzymes and exhibit weak activity (as observed with 9, 10, and 12), a new generation of more potent compounds, such as $\mathbf{1 3}$ and $\mathbf{1 4}$ (SGI-1027 analogs $)^{52,53,54}$, has been identified. However, the potency of these compounds needs to be improved, in particular in cells. In addition, most are not selective for one DNMT isoform. Here we briefly summarize the strategies that have been developed over the last decade to discover new DNMT inhibitors and describe a few examples (Figure 2) and their biological activity (Table 1). 
In parallel, several chemical strategies have been implemented for the discovery of nonnucleoside analogs, starting with phenotypic observations of cellular DNA demethylation (as with $\mathbf{8 , 9}$ and 12, for example) and leading to specialized drug discovery programs based on rational design (as for 9) or virtual and enzymatic screening.

Indeed, numerous assays amenable to high-throughput screening (HTS) have been in use since 2008, as reviewed by Eglen and Reisine. ${ }^{55}$ Several virtual screening programs have also been performed, which were not systematically followed by confirmation of inhibitory ability in biochemical assays. A few HTS campaigns selected among the most representative in the literature are reported here below.

The first virtual screening against DNMT1 led to the identification of $\mathbf{1 1}$ and triazolopyridine derivative (NSC303530, Figure 2) from the NCI database with use of a 3-D model of human DNMT1 (Figure 2) ${ }^{56}$ Compound 11 was further studied and was shown to inhibit in vitro bacterial C5 DNA methyltransferase M.SssI and to demethylate certain promoters in several cancer cells (Table 1). ${ }^{57,58}$ Subsequently, 15 (maleimide derivatives of 11), ${ }^{59}$ a benzoylpyrrolidine analog and a thionitropyridine analog ${ }^{50}$ were synthesized, conferring increased inhibitory properties in enzymatic assays (Figure 2). These studies highlighted that, depending on the experimental conditions of the enzymatic assay (the choice of the C5 DNA methyltransferase, the concentration of the cofactor, the concentration and nature of the DNA duplex and the method of detection), the inhibitory potency can vary greatly for the same compound. More importantly, we learned that the development of enzymatic assays is a critical issue in the field.

By virtual screening, Kuck et al. identified several small molecules from the NCI database, which were then tested at $100 \mu \mathrm{M}$ concentrations against DNMT1 and -3B. The greatest inhibition of DNMT3B was obtained with a salicylic acid dimer (NSC14778, Figure 2) ${ }^{60}$ exhibiting 60\% 
inhibition at $100 \mu \mathrm{M}$, resulting in a weak starting point for chemical modulation. Benzamide derivative (NSC319745, Figure 2) ${ }^{60}$ was the most potent and selective inhibitor of DNMT1 (36\% inhibition at $100 \mu \mathrm{M})$. Twenty-nine analogs of this compound were synthesized and evaluated for their inhibitory activity against DNMT1 and DNMT3A by Kabro et al.. ${ }^{61}$ Although the potencies were sometimes improved compared with the starting hit, only a weak inhibition was obtained (the best $\mathrm{EC}_{50}$ value, $36 \mu \mathrm{M}$, was the measured for the phenol derivative against DNMT3A, Figure 2).

Other virtual HTS efforts have been performed, including one leading to the identification of "natural-like" hits, ${ }^{62}$ and one searching for DNMT1 inhibitors by using 7 as a reference compound..$^{63}$ All these compounds await further biological confirmation.

In parallel, several enzymatic HTS programs were developed for murine Dnmt3A, human DNMT1 and bacterial M.SssI. Compound 16 (3-chloro-3-nitroflavanones, Figure 2), active in the micromolar and submicromolar range (Table 1), was identified in a screen of 114 compounds against the murine Dnmt3A/3L catalytic complex. ${ }^{48}$ Some of these were specific for DNMTs and inactive against histone lysine methyltransferase (HKMT) G9a and they showed an azacitidine phenotype in zebrafish embryos. The same HTS effort was extended to a chemical library of 1120 compounds, from which were identified 17 (diclone, Figure 2 and Table 1), and phenolic inhibitors that reactivated YFP (yellow fluorescent protein) gene expression under the control of a methylated CMV (cytomegalo virus) promoter by inducing its demethylation ${ }^{64}$

An HTS using truncated DNMT1 identified nine hits, including anthraquinone derivatives, such as 18 (laccaic acid, Figure 2) ${ }^{65,66}$ This compound was shown to be a reversible DNA competitor and an inducer of specific tumor suppressor gene expression in breast cancer cells, MCF7 (Table 1). 
More recently, a library of 180,000 compounds was screened in a scintillation proximity assay (SPA) against murine Dnmt3A, followed by a series of filters to discard false positive compounds; they were then evaluated against human DNMT1 ${ }^{67}$ Twelve hits were identified, but a more precise evaluation indicated that these compounds generated $\mathrm{H}_{2} \mathrm{O}_{2}$. A re-examination of the whole series permitted the selection of an additional hit for DNMT1 $\left(\mathrm{IC}_{50}=1.2 \mu \mathrm{M}\right), 19$ (SW155246, Figure $2),{ }^{67}$ which did not generate reactive oxygen species (ROS). Further experiments demonstrated that 19 was more potent against DNMT1 compared with Dnmt3A or DNMT3B/3L, inhibiting global methylation in HeLa cells and reactivating the RASSF1 tumor suppressor gene in A549 cells (Table 1). However, very close analogs of $\mathbf{1 9}$, such as the non-phenolic or the methoxyderivative (structures not disclosed), were found to be inactive. An explanation for this lack of activity implicates activity cliffs, as was recently revealed by docking studies.$^{68}$

In 2004, Cunningham et al. ${ }^{69}$ used a cell-based HTS to identify four acridine derivatives (structures not disclosed) that strongly increase the expression of reporter systems in eight different cancer models. In 2013, the same authors extended their findings by describing these well-known DNA intercalators as inducers of DNA demethylation of tumor suppressor genes and their reexpression in HCT116, RKO and MiaPaCa2 cell lines. Compound $20(517328)^{70}$ was shown to be the most efficient ( $5 \mu \mathrm{M}$ range) and depleted DNMT1 at the promoters of the re-expressed genes in treated cells (Figure 2 and Table 1).

Altogether, the hit rate of the screening campaigns certainly remains low, and selective activity against DNMTs by most of the identified compounds warrants further validation in cellular models. The results overall appear insufficient to elaborate medicinal chemistry programs based on a solid rational approach. This relative lack of positive results suggests that DNMTs are poorly druggable, as evidenced by various techniques employed during the last decade. 
What are the possible causes of failure? Are there specific troubles and difficulties due to the nature of the methyltransferases or enzymes using the SAM co-factor? Apart from the investigations of DNMTs, a considerable amount of work was undertaken in the search for inhibitors of histone methyltransferases. For example, the first G9a lysine methyltransferase inhibitor, 21 (BIX-01294, Figure 3), was identified early in 2007 among a chemical library of 125,000 compounds. ${ }^{71}$ Subsequently, medicinal chemistry efforts afforded pyrolidinopropyl derivative UNC0638 72 and then difluoro derivative UNC0642 (Figure 3) for which the drug properties are improved (potency, selectivity, cellular activity and in vivo pharmacokinetic properties). ${ }^{73}$ However, the in vivo efficacy of these derivatives has not yet been published at this time (Q2 2014) and the proof of concept of their antitumor activity through the inhibition of G9a has not been demonstrated, despite extensive chemical and pharmacological research over these years. Many efforts are still underway, and more recently, a new scaffold was shown to efficiently and specifically inhibit $\mathrm{G} 9 \mathrm{a}$, both in vitro $\left(\mathrm{IC}_{50}\right.$ of $3.3 \mathrm{nM}$ for $\mathrm{A}-366$, Figure 3$)$ and in cancer cells, by competing with the peptide substrates. ${ }^{74}$

In 2012, three independent HTS campaigns performed by three pharmaceutical companies (Epizyme, GSK and Novartis) aiming at identifying potential inhibitors of the HKMT EZH2 were reported. Several million compounds have been tested, but only one unique pharmacophore 22 (a substituted 2-pyridone nucleus, Figure 3) was identified. ${ }^{75,76,77}$ At this time, only one additional series of EZH2 inhibitors bearing a tetramethylpiperidine moiety distinct from 2-pyridone CPI413 (Figure 3), has been described as a tool for in vitro evaluation. ${ }^{78,79}$ In addition, an unusually high number of false positives were observed during the EZH2 screening conducted by GSK, most likely due to non-UV active contaminants not detected by standard HPLC techniques, as highlighted by Diaz et al.. ${ }^{80}$ 
A comparable situation was found in the search for inhibitors of protein arginine methyltransferases (PRMTs) of histone. Indeed, identification of molecules inhibiting PRMTs by means of HTS or rational design is still at an early stage, as described by Fontan et al. and references therein. ${ }^{81}$ The first HTS effort targeting PRMT was published in $2004,{ }^{82}$ and the majority of the compounds identified over the last decade are still regarded as starting points by the authors themselves. Noteworthy, in contrast to lysine methyltransferases, most of the hits identified as potential PRMTs inhibitors are not SAM-competitive.

All these facts, observations and failures reflecting the experimental reality, illustrate the particular difficulties in clearly identifying a bona fide methyltransferase inhibitor. Regarding DNMT, besides the above described nucleoside analogs that have been approved, and those currently in clinical trials, that are potent inhibitors, triggering DNA demethylation in cancer cells, the chemo-diversity explored until now appears not to be sufficient to offer more attractive starting points to medicinal chemists for the design of potent non-nucleoside inhibitors. Still, it is clear that aberrant DNA methylation plays a major role in cancer formation and maintenance, ${ }^{6}$ and the recent clinical results demonstrating the reprogramming by demethylating agents is quite promising for cancer treatment. ${ }^{26,27,83}$ The azanucleosides remain the most potent inhibitors, but they are not selective and specific for the DNMTs. Thus, there is still a great need to find new non-nucleoside DNMTi that strongly inhibit the catalytic activity of the DNMTs.

\section{2/ Advantage of the non-nucleoside analogs: potential selectivity towards one DNMT.}

The main advantage of non-nucleoside inhibitors, which do not need to be incorporated into DNA, is that it is possible to identify inhibitors selective towards each of the DNMT isoforms. Selectivity is an important issue to address because DNA methylation is also involved in normal 
biological processes. Today, it is not clear which DNMT would be the "best" therapeutic target. Furthermore, outcomes may depend on the pathology: for example, in certain leukemias ${ }^{84}$ and melanomas ${ }^{85,86}$ mutations or overexpression of DNMT3A is observed, whereas in certain prostate, breast and colon cancers as well as in gliomas, it is DNMT3B that is overexpressed, and in others it is DNMT1. ${ }^{25}$ Selective inhibitors will allow researchers to address this question and perhaps identify which DNMT is the most relevant therapeutic target. These selective inhibitors would also increase our knowledge about the methylation process in cancers to gain useful information about protein interaction partners and signaling pathways and to better understand the differences in the catalytic pocket of the enzymes and their mechanism of action in cancer cells, all of which contributes to the identification of personalized treatments. Finally, selective inhibitors of DNMT1 or DNMT3 should show decrease side effects.

DNMTs are enzymes that bind two substrates: the cytosine moiety, flipped out of the DNA double helix for methylation, and the SAM that donates the methyl group. Both binding pockets could be targeted, either individually or together. Considering the DNA pocket and its targeting by nucleoside analogs, we have previously discussed that, because of their mechanism of action (incorporation into DNA, Figure 1B), $\mathbf{1}$ and $\mathbf{2}$ cannot be chemically selective for one isoform of DNMTs. ${ }^{31,45}$

Can this selectivity be achieved?

Considering the SAM pocket, it should be kept in mind that the SAM cofactor is the main methyl donor in cells; it is used by all methyltransferases. Analogous to the kinases, it has been clearly demonstrated that it is possible to conceive ATP mimetics that selectively inhibit one tyrosine kinase among the others. ${ }^{87}$ Can the same be true for SAM and the DNA methyltransferases? Again, we can learn from the other epigenetic methyltransferases, in particular the widely studied 
HKMTs. In the literature, some examples of selective inhibitors of HKMT already exist (Figure 4). Compound 21 is a G9a/GLP inhibitor, inhibiting only these enzymes among the SET domain lysine methyltransferases because of its interaction with helix $\alpha \mathrm{Z}$, a domain present only in G9a and GLP. ${ }^{88}$ Compound 21 fits into the peptide binding site of the enzyme. Selective inhibitors of EZH2/1 were also described, such as dihydropyridinone (EPZ005687) in Figure 4. ${ }^{75,77,89}$ Yao et $a l$. showed that the SAM pocket can also offer good selectivity in methyltransferase inhibition, exemplified by DOT1L,$^{90}$ which has attracted interest because it is the only PKMT that does not contain the SET domain (the DOT1L inhibitor in clinical trials, EPZ004777, is depicted in Figure 4).

The catalytic pockets of the DNA methyltransferases (ten catalytic motifs) are highly conserved..$^{15}$ The motifs contain two pockets: (i) one that will host the deoxycytidine to be methylated, which is flipped out of the DNA double helix and inside the active pocket of the enzyme, where the catalytic cysteine of the proline-cysteine motif establishes a covalent bond at position 6; and (ii) the SAM pocket. In Figure 5, we superimposed the catalytic pockets of the crystal structures of murine Dnmt1 (PDB: 4DA4) and murine catalytic DNMT3a (PDB: 2QRV). Although the peptide sequence of the catalytic pocket is highly conserved and the two pockets are very similar in their 3D structure, the comparison of the catalytic pockets of Dnmt3A and Dnmt1 as revealed by these crystal structures suggests that it should be possible to design selective inhibitors of each enzyme.

The position of the $S$-adenosyl-L-homocysteine (SAH, depicted in pink in Dnmt1 and in yellow in Dnmt3A), a natural product of the methylation reaction, is well conserved in the two isoforms, and hydrogen bonds strongly stabilize it. Although the deoxycytidine unit is not resolved in the Dnmt3A structure as it is in the Dnmt1 structure (in pink), we can observe that the DNA pockets 
occupy similar interaction spaces in both enzymes. However, some amino acids are different, as highlighted in Figure 5. Trp1173 in Dnmt1 is replaced by Cys662 in Dnmt3A, Asn1580 by Arg887 and Val1582 by Trp889. These replacements induce different interaction features, suggesting that it is possible to design selective compounds addressing these differences. As one example, tryptophan is an aromatic amino acid offering a $\pi$-stacking interaction,,${ }^{91}$ which is impossible with cysteine; similarly, arginine is well-known for its ability to provide multiple hydrogen bonds differently from the other amino acids..$^{60}$

In agreement with these observations, some inhibitors were described to be specific for DNMT1 or DNMT3. Compound 8 was the first DNMT inhibitor that exhibited some selectivity for DNMT1, owing to its greater affinity for hemi-methylated DNA. ${ }^{47}$ Wahhab et al. were able to confer DNMT3B or DNMT1 selectivity to adenine derivatives. ${ }^{92}$ More recently, 23 (nanaomycin A), a natural compound, was shown to be a specific inhibitor of DNMT3B (Table 1). ${ }^{93}$ However, these drugs are not very potent (0.1-1 M range), thus necessitating improvement, and none were described to be selective for the $3 \mathrm{~A}$ isoform. Nevertheless, selectivity seems possible and is certainly of interest both for understanding the methylation cascade in cancer cells $v s$. normal ones and for developing more specific anti-cancer drugs.

A better knowledge of the X-ray crystal structures of the DNMT machinery in the presence of the inhibitors that have been identified would be of great help to engage more rational design of selective inhibitors.

\section{3/ Are there alternative ways to modulate and to inhibit DNMTs?}

Figure 6 shows schematically the different options that can be developed to inhibit DNA methylation. On one hand, as described above, it will be interesting to develop SAM analogs for 
DNMTs, as it has been done for HKMTs. This search has not been systematically reported for DNMTs. Most of the screening assays were not designed for this purpose, and were carried out at a high concentration of cofactor, which were needed for better enzymatic activity in vitro. Indeed, in the screening assay we developed against catalytic Dnmt3A/3L,${ }^{94}$ a high concentration of SAM, $20 \mu \mathrm{M}$, was used, with the result that only very potent and optimized SAM competitors could be identified. Radioactive assays based on the incorporation of tritiated methyl groups are more suitable to discover inhibitors that compete with SAM because micromolar or submicromolar amounts of SAM are used ${ }^{67,95}$ Interestingly, Rotili et al. have shown that it is possible to start from an inhibitor of lysine methyltransferase, the G9a/GLP inhibitor BIX-01294, to design a specific inhibitor of DNMTs by chemical modifications (quinazoline derivative, Figure 2). ${ }^{96}$

On the other hand, DNA binders can also function as inhibitors of DNMTs by preventing the enzyme from binding and executing its catalytic activity. Strong, well-known DNA ligands, such as minor groove binders that are used for microscopy (e.g. Hoechst 33342) and common DNA intercalators, such as $\mathbf{2 0}$ (Figure 2 and Table 1), are frequent hits found in DNMT screens ( ${ }^{66,67}$ and data not shown). ${ }^{70}$ To develop DNA ligands as inhibitors of DNA methylation, it is important to keep in mind the need for selectivity towards $\mathrm{CpG}$ islands and, ideally, tumor suppressor promoters that are hypermethylated in cancer. Compound 7 (Figure 2) was rationally designed from a family of minor groove binders. ${ }^{46}$ It is the most promising non-nucleoside inhibitor, with micromolar inhibitory potency in enzymatic assays, specifically demethylating tumor suppressor genes in cancer cells and reactivating them (Table 1). It was subsequently chemically modulated to obtain new derivatives 13 and 14 of equal potency ${ }^{52,53}$ or to achieve more potent inhibitors in vitro (structures not disclosed), inhibiting cancer stem cells' growth..$^{54}$ The main limiting factor with this approach is the specificity towards certain DNA sequences, the CpG islands and, in particular, the 
promoters of tumor suppressor genes, without affecting other proteins that recognize and bind DNA. The use of sequence-specific DNA ligands is a promising option. Minor groove binders, such as hairpin pyrrole-imidazole polyamides (structure not disclosed) binding specifically to 5'CGCG-3' sites, were reported to strongly inhibit in vitro M.SssI DNA methylation ( $\mathrm{IC}_{50}$ in the nanomolar range) ${ }^{97}$ It would be particularly interesting to develop inhibitors that are competitors of the DNA substrate, i.e., deoxycytidine, without binding to DNA. Certainly, these molecules would be more specific because fewer proteins recognize flipped cytosines..$^{98} 99$

Finally, the most specific approach would be to combine the two substrates, SAM and cytosine/deoxycytidine, in a single molecule. It is a common approach, called the "multisubstrate adduct" approach (i.e., the covalent attachment of two substrates of an enzyme to form a single molecule), applied to enzymes binding two substrates such as the DNA methyltransferases. This method has been shown to increase the binding affinity and specificity for the target enzyme. Such an approach was used, for example, for a bacterial adenine DNA methyltransferase. ${ }^{100}$

Another approach involves directly targeting interactions of DNMTs with its protein partners, rather than directly targeting it and its catalytic pocket. As other epigenetic actors, DNMTs are involved in multiprotein complexes that crosstalk to regulate chromatin status. Examples of such interactions are the DNMT3A/3L interface that was discovered in 2007 in a crystallographic study ${ }^{17}$, constituting a potential target, ${ }^{101}$ as well as the UHRF1/DNMT1 interaction, which is important for the recruitment of DNMT1 to hemimethylated DNA. ${ }^{102,}{ }^{103}$ To the best of our knowledge, this strategy has not yet delivered a validated DNMT inhibitor, but preliminary results appeared very recently in the literature. Peptides were found that are able to disrupt the interactions of DNMT with its protein partners CFP1 ${ }^{104}$ In addition, several successful approaches that used this strategy have been described, and at least two examples relating to epigenetics were reported. 
Again, the approach encompasses the inhibition of histone methyltransferases. Stapled peptide inhibitors of the interaction between EZH2 and EED, a feature of the PRC2 complex, have been synthesized and proven to reduce EZH2 protein levels in leukemia cells. ${ }^{105}$ More recently, Cao et $a l .{ }^{106}$ described the disruption of interactions between MLL1, a lysine methyltransferase, and WDR5, a protein partner critical for the integrity of the core complex, by using macrocyclic peptidomimetics, leading to the inhibition of MLL1 methyltransferase activity. This pioneering work has delivered proof of concept in dedicated cellular assays. The validation of the approach in in vivo models will represent a landmark actualization of this strategy for protein-protein interaction inhibition.

\section{4/ Thoughts about the inhibition of DNA methylation in cells}

All non-nucleoside inhibitors, even the most potent, induced only weak DNA demethylation in cells (Table 1). Several reasons might explain this lack of cellular activity: drug solubility, weak cell or nuclear penetration, and so forth. However, some of the compounds are cytotoxic in the micromolar or submicromolar range, suggesting that these compounds have a biological effect in cells and thus appear to enter cells. Another issue is the potency that is required in the in vitro enzymatic assays to observe a cellular effect on DNA methylation: $\mathrm{nM}$ or $0.1 \mu \mathrm{M}$ ? It is difficult to answer this question because first the enzymatic assays exhibit different features, thus, differences in $\mathrm{IC}_{50}$ are observed, making it impossible to define a value common to all assays. Second, there is no reference catalytic (or allosteric) inhibitor that is sufficiently potent to calibrate these tests in cells, and last, the azanucleoside inhibitors cannot be used to calibrate the in vitro enzymatic assays because they need to be incorporated into DNA to be active, forming a suicide complex. In fact, the irreversible covalent complex formed by $\mathbf{1}$ and $\mathbf{2}$ is further processed by the 
cell, and the DNMT is degraded ${ }^{45,107}$ Thus, these inhibitors induce a loss of methylation by trapping and degrading the DNMTs.

How do catalytic inhibitors of DNMT function in cells and demethylate DNA? Active DNA demethylation has been deeply studied, and no DNA demethylase had been clearly identified until 2009, when 5-hydroxymethylcytosine and the TET1,2 enzymes were found ${ }^{108,109}$ to be involved, via the DNA repair machinery, in active DNA demethylation. ${ }^{110}$ Nevertheless, the catalytic inhibitors of DNMTs are expected to inhibit the methylation reaction performed by the DNMTs and thus act via a passive loss of methylation. During replication, the methylation pattern of the parent strand is copied on the newly synthetized strand by DNMT1 but also by DNMT3A and DNMT3B. ${ }^{15}$ If, during this process, the DNMTs are $100 \%$ inhibited, $50 \%$ of DNA methylation is lost per replication cycle (Figure 7, open circles). Theoretically, 3 to 4 doubling times are needed for $90 \%$ inhibition of DNA methylation, strictly assuming a process of passive DNA demethylation during replication (Figure 7). This is similar to what observed upon use of $\mathbf{1}$ and $\mathbf{2}$, forming suicide complexes with the enzyme. Commonly, low doses of the two drugs are added to the cells repetitively, for example, daily over $72 \mathrm{~h} .{ }^{111}$ However, we do not expect $100 \%$ inhibitory potency with the catalytic inhibitors. If the compound induces $50 \%$ inhibition, 8 to 9 doubling times are needed to obtain a $90 \%$ loss of DNA methylation (Figure 7, closed rhombus), and more doubling times are needed for less potent inhibitors. This calculation does not consider any de novo methylation that may take place or its inhibition. Thus, if the inhibitors act only by passive loss of methylation, long treatment times are needed, and demethylation must be evaluated several weeks after treatment, depending on the doubling time of the cell line. Most studies were carried out between $24 \mathrm{~h}$ and $72 \mathrm{~h}$, with the exception of those on $\mathbf{1 1 ^ { 5 7 }}$ and $\mathbf{7}^{46}$, which were extended to 15 days. However, this is a theoretical calculation based only on passive loss of DNA methylation 
during the maintenance of DNA methylation; it must not be excluded that these compounds may trigger active demethylation mechanisms that are not yet identified.

Nevertheless, it is worth considering longer treatment schedules and increasing the inhibitory potency of the compounds as well as studying the design of inhibitors that form covalent bonds once bound to the enzyme, as observed with neratinib, a tyrosine kinase inhibitor. ${ }^{87}$.

\section{5/ What are the expected features of the new generation of DNMT inhibitors?}

Indeed, both available approved drugs $\mathbf{1}$ and $\mathbf{2}$, together with $\mathbf{4}$, which is currently in advanced clinical trials, are covalent inhibitors of DNMTs. A covalent inhibitor can be considered the most powerful type of compound, as the target enzyme is consequently $100 \%$ inactivated. Thus nonnucleoside inhibitors that form covalent bonds with the enzymes could be an ideal option.

In addition, selectivity among the DNMT isoforms could be achieved because of differences in the amino acid sequence in the SAM binding pocket and in the deoxycytidine pocket, as discussed above. Medicinal chemistry efforts should be able to achieve this goal. Still unanswered is the problem of which isoform to target, even though several reports have addressed this issue by using knock-downs ${ }^{112,113,114}$ or knock-out strategies. ${ }^{115}$ Selective chemical probes will be of great use to explore this point for an in vitro evaluation in cells and an in vivo study of the anti-tumor activity of the targeted DNMT. However, an inconvenience of covalent inhibitors is that the active chemical agents appended to the inhibitors (such as Michael acceptors) to form a covalent bond may cause some toxicity.

Allosteric DNMT inhibitors have not been identified to date but represent an interesting category of molecules, even if we do not know, in the absence of such a reference compound, the degree of potency that is needed to obtain DNA demethylation in cells. 
Because it is difficult to target the catalytic pocket of DNMTs, an alternative and promising option is to disrupt the interaction of the DNMTs with their protein partners by using small molecules. In particular, this could result in increased specificity for cancer treatment because it is possible that different forms of regulation are involved in normal cells $v s$. cancer cells. In the latter, aberrant epigenomes are observed, and many genetic mutations have occurred, altering normal signaling pathways. ${ }^{7}$

Prolonged cellular treatments should be considered, in particular for non-covalent inhibitors, or, at the least, the analysis of cellular effects should be followed for several doubling times. We cannot yet predict the manner in which the cells will adapt to these modifications during this period. The results with $\mathbf{1}$ and $\mathbf{2}$ are encouraging for this hypothesis. ${ }^{11}$

Finally, as mentioned in the Introduction, combinations with other epidrugs, chemical agents and immunotherapies open the road to new ways of managing cancer (Figure 6). The actors in epigenetic regulation are tightly interconnected. For certain promoters, DNA demethylation is not sufficient to reactivate the expression of the corresponding genes. Combining with HDAC inhibitors further opens the promoter to the transcriptional machinery. Combinations with inhibitors of other gene silencing actors (such as G9a, EZH2 or lysine histone demethylases) are worth exploring. In addition, DNA demethylation induces cell reprogramming, favoring several phenotypes, ${ }^{10}$ such as the reactivation of pathways involved in the response to standard chemotherapeutic agents (such as doxorubicin) $)^{27}$ or in the immunoresponse. ${ }^{83}$

In conclusion, DNA methylation and DNMTs constitute a very promising but challenging anticancer target. Aside from the azanucleoside inhibitors (oral formulations, drug combinations and pro-drug strategy) for which extensive clinical trials are ongoing and represent the next generation 
of DNMTs inhibitors, all the results reported in the literature related to the search for nonnucleosidic inhibitors suggest that these enzymes are poorly druggable with respect to the identified compounds until now. Therefore, the future challenge is to discover potent and selective non-nucleoside inhibitors able to induce DNA demethylatation in cancer cells. 


\section{FIGURES}

A)<smiles>Nc1ncn([C@@H]2OC(CO)[C@@H](O)[C@H]2O)c(=O)n1</smiles><smiles>Nc1ncn([C@@H]2C[C@H](O)[C@@H](CO)O2)c(=O)n1</smiles><smiles>O=c1ncccn1[C@@H]1C[C@H](O)[C@@H](CO)O1</smiles><smiles>Nc1ncn([C@H]2C[C@H](CO)[C@@H](OP(=O)(O)OC[C@H]3O[C@@H](n4cnc5c(=O)[nH]c(N)nc54)C[C@@H]3O)O2)c(=O)n1</smiles>

2, Decitabine

3, Zebularine<smiles>O=C1N[C@@H](O)CCN1[C@@H]1O[C@H](CO)[C@@H](O)[C@H]1O</smiles><smiles>[R]C1([R])OC(CO)[C@@H](O)[C@@H]1N1CC[C@@H](O)NC1=O</smiles>

4, SGI-110

5, Tetrahydrouridine (THU)

6, THU derivatives

$\mathbf{6} \mathbf{a}=\mathrm{R}_{1}, \mathrm{R}_{2}=\mathrm{H}$

$\mathbf{6 b}=\mathrm{R}_{1}, \mathrm{R}_{2}=\mathrm{F}$

B)
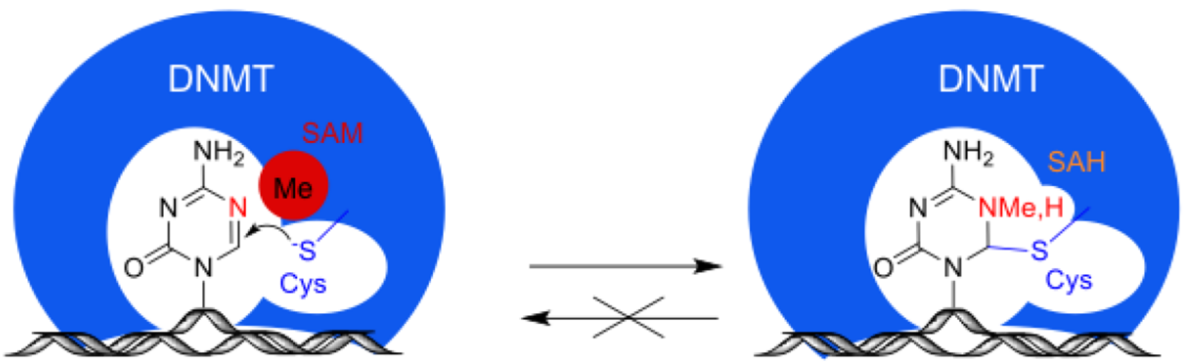

suicide complex

-protein degradation

-DNA repair

-loss of DNA methylation

Figure 1 - A) Chemical structures of the main nucleoside inhibitors of DNMT. 6 is the general chemical formula for THU derivatives. B) Schematic representation of the formation of an irreversible covalent complex between the enzyme and DNA at the 5-azacytosine site. 
$\underline{\text { SGI-1027 and derivatives }}$

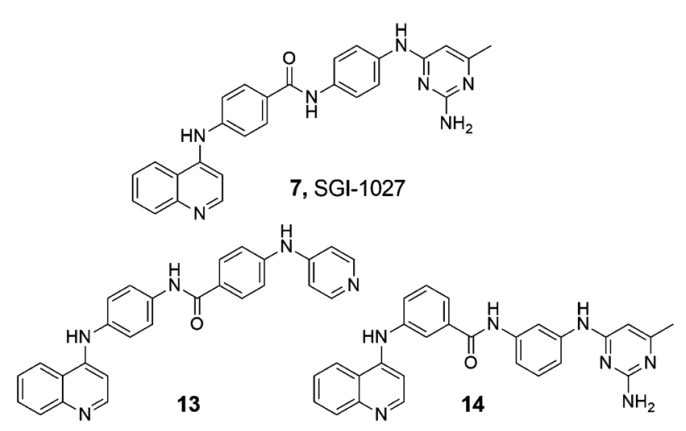

Flavonoids

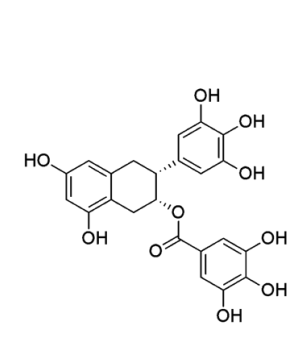

9, EGCG
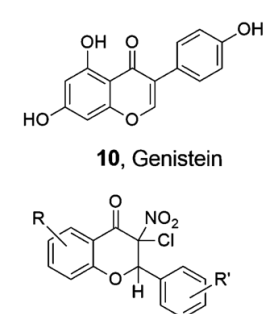

16, 3-Chloro-3-nitroflavanones
Procainamide and derivatives
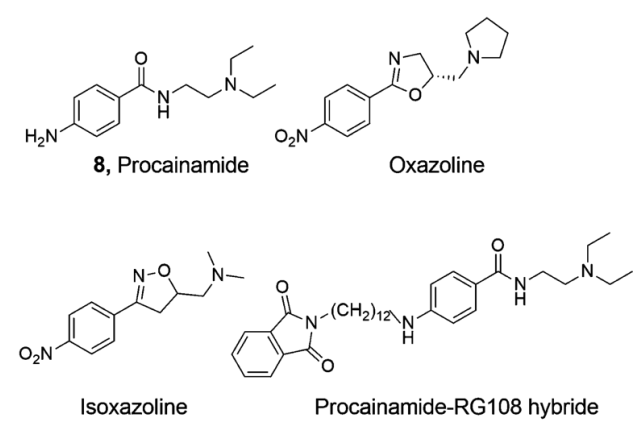

RG108 and derivatives
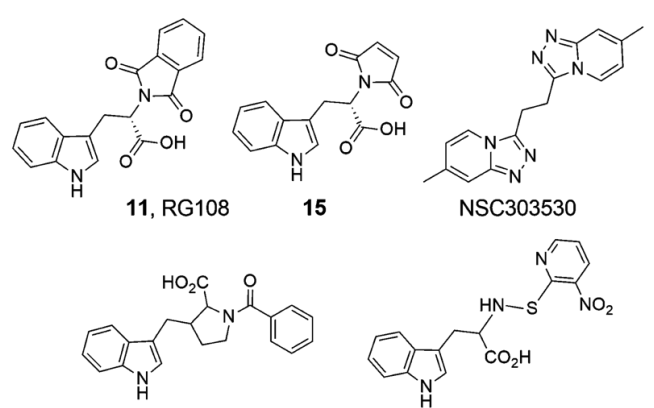

pyrrolidino benzoyl analog

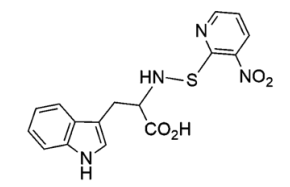

thionitropyridine analog

Miscellaneous

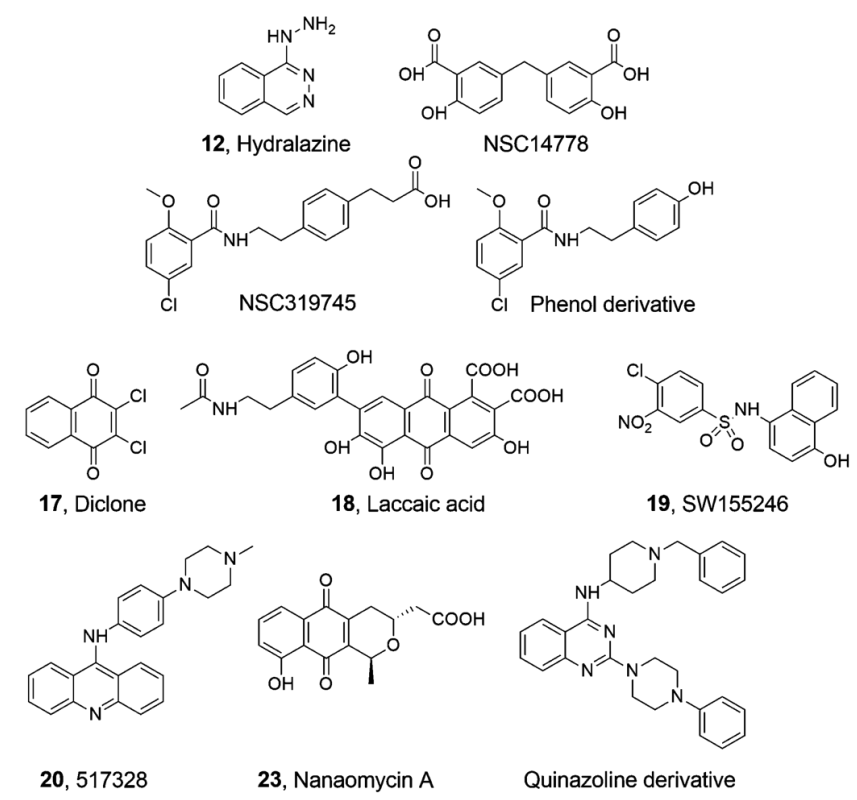

Figure 2 - Chemical structures of the most studied non-nucleoside inhibitors regrouped by chemical family. 

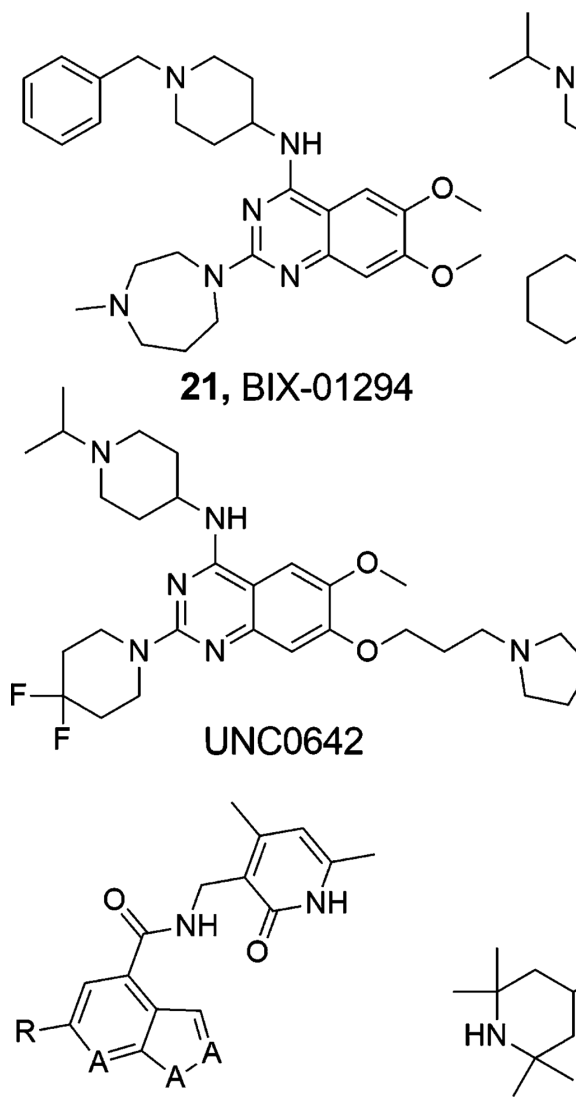

22, Typical EZH2 inhibitor
UNC0638

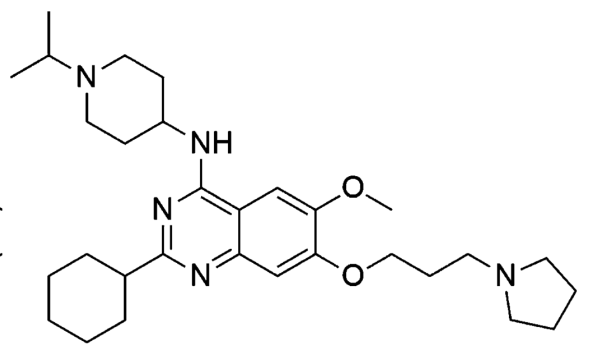<smiles>Cc1c(Oc2ccc(C(=O)NC3CC(C)(C)NC(C)(C)C3)cc2Cl)cccc1-c1ccnnc1</smiles>

$\mathrm{CPI} 413$

Figure 3 - Main inhibitors of the histone lysine methyltransferases G9a and EZH2. 22 represents the general chemical formula for EZH2 inhibitors. 

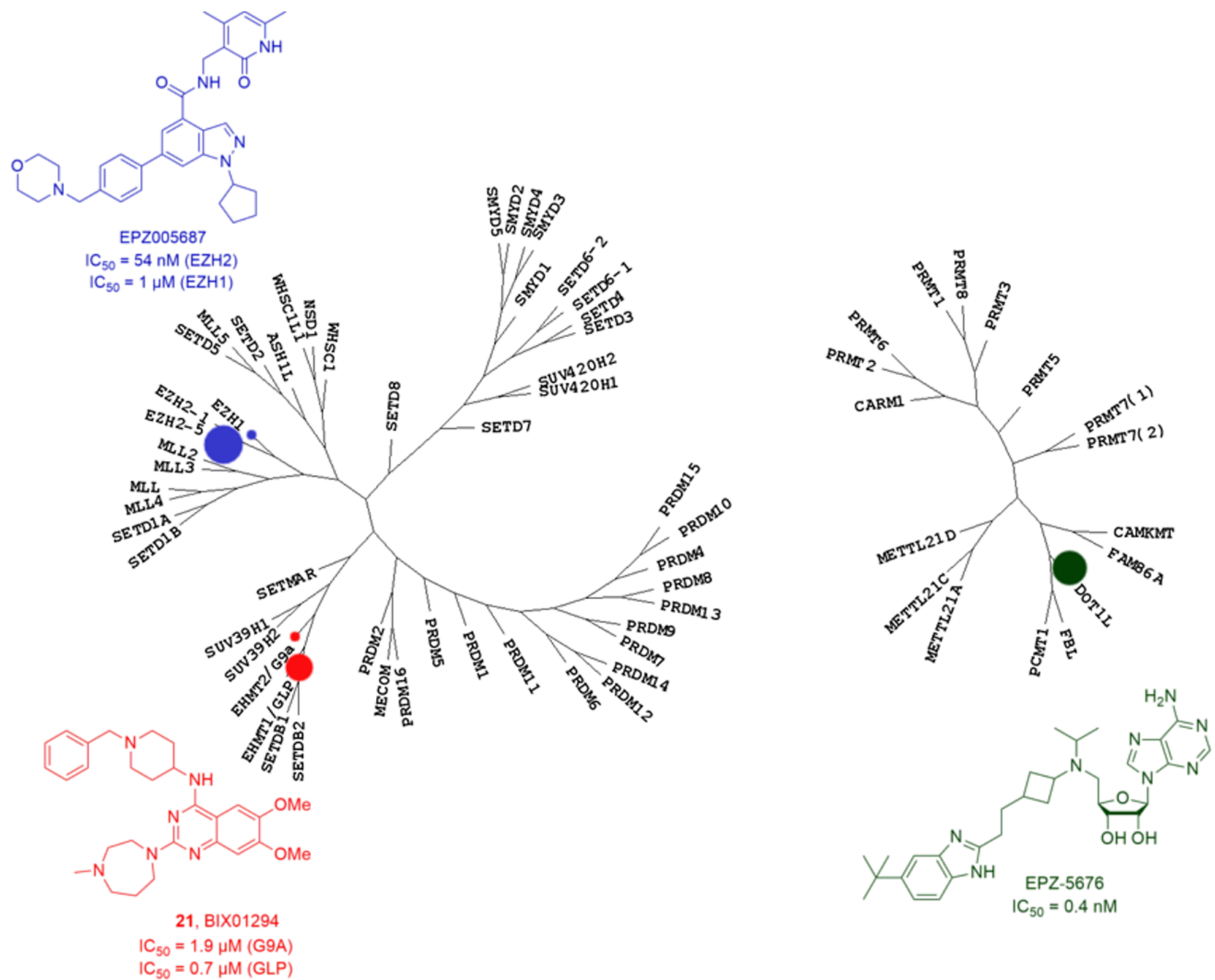

Figure 4 - Examples of selective inhibitors of histone lysine methyltransferases. The HKMT tree was created on the SGC website (www.thesgc.org). The selective inhibitors of DOT1L, EZH2 and G9a/GLP are depicted in green, blue and red, respectively. The size of the circles is representative of the potency of the inhibitor. 


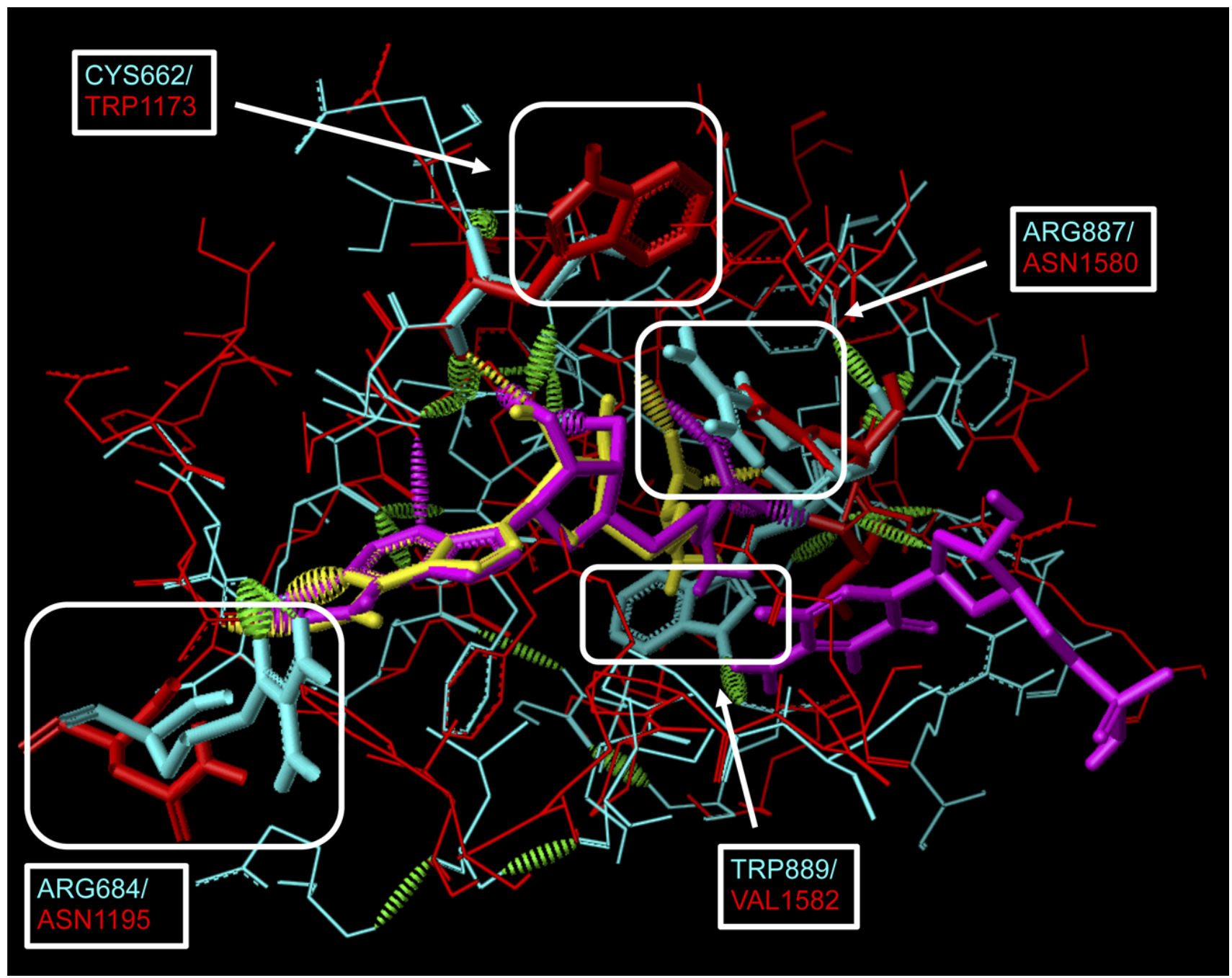

Figure 5 - The catalytic pocket in the crystal structure of Dnmt3A (PDB: 2QRV, the enzyme is depicted in cyan) was superposed on the one in the crystal structure of Dnmt1 (PDB: 4DA4, the enzyme is in red). The natural ligands of Dnmt1 (SAH and deoxycytidine) are shown in purple, and the SAH in Dnmt3A is in yellow. Deoxycytidine was not resolved in the Dnmt3A/Dnmt3L crystal structure at the difference of the Dnmt1 structure. The main differences in amino acids are highlighted in white boxes. 


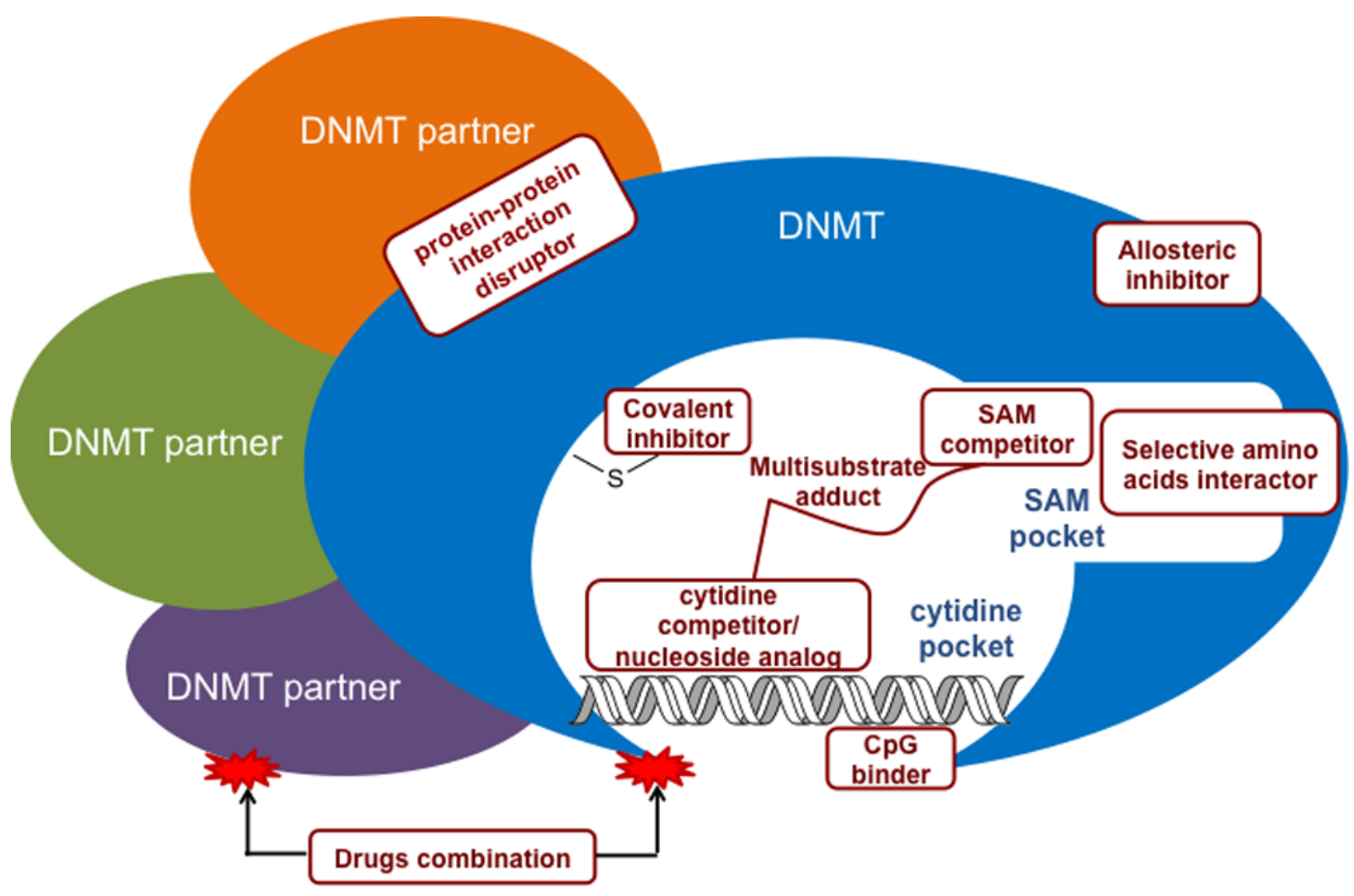

Figure 6 - Schematic representation of the different inhibition strategies to target DNMT. 


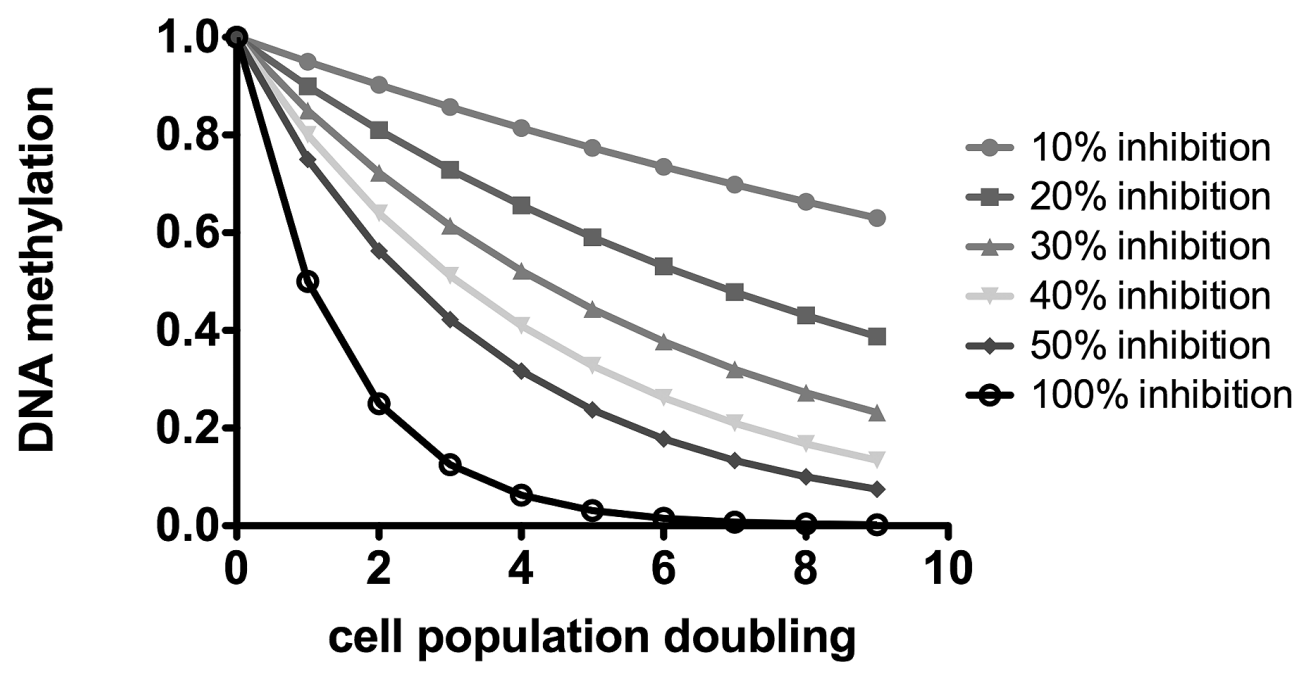

Figure 7 - Passive loss of DNA methylation in cells due to the inhibitors, according to their inhibitory efficacy. The graphs were obtained by using the following equation:

$$
\text { DNA methylation }=(1-x / 2)^{n}
$$

where the maximum of DNA methylation is $1, x$ is the inhibitory efficacy $(0 \leq x \leq 1)$ and $n$ the doubling time. 
Table 1. Summary of the foremost inhibitors and their biological properties.

\begin{tabular}{|c|c|c|c|c|c|c|c|c|}
\hline \multirow{2}{*}{\multicolumn{2}{|c|}{ Compounds }} & \multicolumn{3}{|c|}{$\begin{array}{l}\text { in-vitro enzymatic } \\
\text { inhibition }\left(\mathrm{IC}_{50}, \mu \mathrm{M}\right)^{\mathrm{a}}\end{array}$} & \multicolumn{2}{|c|}{ Cellular activity } & \multirow{2}{*}{ Mechanism } & \multirow{2}{*}{ Refs } \\
\hline & & $\begin{array}{c}\text { DNMT } \\
1\end{array}$ & $\begin{array}{c}\text { DNMT } \\
\mathbf{3 a}\end{array}$ & $\begin{array}{c}\text { DNMT } \\
\mathbf{3 b}\end{array}$ & \begin{tabular}{|c|} 
DNA \\
demethylation
\end{tabular} & $\begin{array}{c}\text { TSG }^{\mathbf{b}} \\
\text { reactivation }\end{array}$ & & \\
\hline \multicolumn{9}{|c|}{ NUCLEOSIDE ANALOGS } \\
\hline \multicolumn{2}{|c|}{$\begin{array}{c}1 \text { (azacitidine) and } 2 \\
\text { (decitabine) }\end{array}$} & \multicolumn{3}{|c|}{$\mathrm{NA}^{\mathrm{c}}$} & \multicolumn{2}{|c|}{ Observed in all tested cell lines } & \multirow{2}{*}{$\begin{array}{c}\text { DNA } \\
\text { incorporation } \\
\text { and enzyme } \\
\text { trapping, } \\
\text { suicide } \\
\text { complex } \\
\text { formation }\end{array}$} & $\begin{array}{l}28,29, \\
30,31\end{array}$ \\
\hline $3(\mathrm{Zeb}$ & ularine) & & NA & & $\begin{array}{r}\text { Observed in most } \\
\text { line }\end{array}$ & $\begin{array}{l}\text { of the tested cell } \\
\text { s. }\end{array}$ & & $\begin{array}{c}41,45 \\
111 \\
116\end{array}$ \\
\hline \multicolumn{2}{|c|}{4 (SGI-110) } & \multicolumn{3}{|c|}{ NA } & $\begin{array}{l}P 16 \text { in T24, } \\
\text { HCT116 and } \\
\text { EJ6 cells }\end{array}$ & $\begin{array}{l}P 16 \text { in T24, } \\
\text { HCT116 and } \\
\text { EJ6 cells }\end{array}$ & $\begin{array}{c}\text { DNA } \\
\text { incorporation } \\
\text { and irreversible } \\
\text { enzyme } \\
\text { trapping }\end{array}$ & $\begin{array}{c}118, \\
119 \\
120 \\
121 \\
122, \\
123, \\
124 \\
125 \\
126 \\
127 \\
128 \\
129 \\
130,131\end{array}$ \\
\hline \multicolumn{9}{|c|}{ NON-NUCLEOSIDE ANALOGS } \\
\hline \multirow{2}{*}{$\begin{array}{l}\text { SGI1027 } \\
\text { derivatives }\end{array}$} & 7 (SGI1027) & 6 & 8 & 7.5 & $\begin{array}{l}P 16, M L H 1, \text { and } \\
\text { TIMP3 in } \\
\text { HCT116 cells }\end{array}$ & $\begin{array}{l}P 16, M L H 1, \\
\text { and TIMP3 in } \\
\text { HCT116 cells }\end{array}$ & $\begin{array}{c}\text { SAM } \\
\text { competitor }\end{array}$ & 46 \\
\hline & 14 & 9 & 2.8 & $\mathrm{ND}^{\mathrm{d}}$ & ND & ND & $\begin{array}{c}\text { DNA } \\
\text { competitive }\end{array}$ & $\begin{array}{c}52,53, \\
54\end{array}$ \\
\hline $\begin{array}{l}\text { Procainamide } \\
\text { derivatives }\end{array}$ & $\begin{array}{c}\mathbf{8} \\
\text { (Procainamide) }\end{array}$ & $>500$ & $>300^{\mathrm{e}}$ & ND & $\begin{array}{l}\text { Weak Global } \\
\text { DNA } \\
\text { demethylation in } \\
\text { MCF7, HL60 and } \\
\text { HCT116 cells. }\end{array}$ & $\begin{array}{c}\text { LINE-1 in T24 } \\
\text { cells. } \\
\text { RAR } \beta 2 \text { in } \\
\text { MCF7 cells }\end{array}$ & DNA ligand & $\begin{array}{c}47,132, \\
133, \\
134,135\end{array}$ \\
\hline
\end{tabular}




\begin{tabular}{|c|c|c|c|c|c|c|c|c|}
\hline & & & & & $\begin{array}{c}\text { TIMP-3 in } \\
\text { HCT116 cells }\end{array}$ & & & \\
\hline & $\begin{array}{l}\text { oxazoline and } \\
\text { izoxazoline }\end{array}$ & 150 & \multicolumn{2}{|c|}{ ND } & $\begin{array}{c}\text { Weak global } \\
\text { DNA } \\
\text { demethylation in } \\
\text { HL60 cells }\end{array}$ & ND & $\begin{array}{c}\text { SAM } \\
\text { Competitor }\end{array}$ & \\
\hline & $\begin{array}{c}\text { procainamide- } \\
\text { RG108 } \\
\text { hybride }\end{array}$ & 4 & $21^{\mathrm{e}}$ & ND & \multicolumn{2}{|c|}{ ND } & $\begin{array}{l}\text { SAM and DNA } \\
\text { competitor }\end{array}$ & \\
\hline \multirow{3}{*}{ Flavonoids } & 9 (EGCG) & 0.5 & & & $\begin{array}{c}\text { Cyclin D2, } \\
R A R-\beta, R A R-\beta 2 \\
\text { and } T M S 1 \text { in } \\
\text { MDA-MB-231 } \\
\text { cells } \\
R A R \beta 2 \text { in } \\
\text { KYSE } 510, \\
\text { KYSE } 150 \text { cells. } \\
R A R \beta 2 \text { and } P 16 \\
\text { in MCF7 cells }{ }^{\mathrm{f}} \\
\text { Global DNA } \\
\text { demethylation } \\
\text { in A431and } \\
\text { SCC13 cells }\end{array}$ & $\begin{array}{c}P 16, M G M T \\
\text { and } R A R \beta 2 \text { in } \\
\text { KYSE } 510, \\
\text { HT29 and PC } 3 \\
\text { cells. } \\
P 16 \text { and } P 21 \text { in } \\
\text { A431 cells }\end{array}$ & $\begin{array}{c}\text { COMT } \\
\text { substrate }\end{array}$ & $\begin{array}{c} \\
\\
\\
48,49, \\
136,\end{array}$ \\
\hline & $\mathbf{1 0}$ (genistein) & 30 & $>100^{\mathrm{e}}$ & ND & $\begin{array}{c}\text { Global DNA } \\
\text { demethylation } \\
\text { in MCF-7 and } \\
\text { MDA-MB-231 } \\
\text { cells } \\
\text { CyclinD2 and } \\
M G M T \text { in } \\
\text { MDA-MB-231 } \\
\text { cells. }\end{array}$ & $\begin{array}{c}R A R \beta 2 \text { in } \\
\text { KYSE } 510, \\
\text { KYSE } 150, \\
\text { LNCaP, PC } 3 \\
\text { cells. } P 16 \text { and } \\
M G M T \text { in } \\
\text { KYSE } 510 \text { cells. } \\
\text { ATM, APC and } \\
\text { PTEN in MCF7 } \\
\text { and MDA-MB- } \\
231 \text { cells. }\end{array}$ & ND & $\begin{array}{c}137 \\
138,139\end{array}$ \\
\hline & $\begin{array}{c}\mathbf{1 6} \text { (chloro- } \\
\text { nitroflavanone) }\end{array}$ & ND & $0.37^{\mathrm{e}}$ & ND & NI & & & \\
\hline Acridine & $20(517328)$ & & ND & & $\begin{array}{l}C D H 13, C D H 1 \\
\text { and } S F R P 1 \text { in } \\
M i a P a C a 2 \text { cells }\end{array}$ & $\begin{array}{l}C D H 13 \text {, } \\
C D H 1 \text { and } \\
\text { SFRP1 in }\end{array}$ & $\begin{array}{c}\text { DNA } \\
\text { intercalator }\end{array}$ & 70 \\
\hline
\end{tabular}




\begin{tabular}{|c|c|c|c|c|c|c|c|c|}
\hline & & & & & $\begin{array}{c}\text { and } S F R P I \text { in } \\
\text { RKO cells }\end{array}$ & $\begin{array}{c}\text { MiaPaCa2 } \\
\text { cells } \\
\text { P16, SFRP1 } \\
\text { and } S F R P 5 \text { in } \\
\text { RKO cells }\end{array}$ & & \\
\hline \multirow[t]{2}{*}{$\begin{array}{c}\text { RG-108 } \\
\text { derivatives }\end{array}$} & 11 (RG-108) & 390 & $315^{\mathrm{e}}$ & \multirow[t]{2}{*}{ ND } & $\begin{array}{l}\text { SFRP } 1, \text { TIMP-3, } \\
\text { andP16 in } \\
\text { HCT116; global } \\
\text { demethylation in } \\
\text { NALM-6, LNCaP } \\
\text { and 22Rv1 }\end{array}$ & $\begin{array}{c}\text { SFRP1, TIMP- } \\
3 \text {, andP16 in } \\
\text { HCT116. } \\
\text { CDH1 in } \\
\text { HL60 cells, } \\
\text { GSTP1, APC } \\
\text { and } R A R \beta 2 \text { in } \\
\text { LNCaP }\end{array}$ & $\begin{array}{c}\text { SAM } \\
\text { competitor }\end{array}$ & \multirow[t]{2}{*}{$\begin{array}{c}48,50 \\
58,133 \\
140, \\
141,14\end{array}$} \\
\hline & $\begin{array}{c}15 \text { (RG-108 } \\
\text { analog) }\end{array}$ & 20 & ND & & ND & ND & $\begin{array}{l}\text { SAM and DNA } \\
\text { competitor }\end{array}$ & \\
\hline \multicolumn{2}{|c|}{17 (diclone) } & 1.6 & $0.5^{\mathrm{e}}$ & ND & $\begin{array}{l}\text { CMVpromoter in } \\
\text { HEK293 cells }\end{array}$ & $\begin{array}{l}\text { CMV-GFP in } \\
\text { HEK293 cells }\end{array}$ & ND & 64 \\
\hline \multicolumn{2}{|c|}{23 (nanaomycin A) } & $\begin{array}{l}\text { in- } \\
\text { active }\end{array}$ & ND & 0.5 & $\begin{array}{l}\text { RASSF } 1 A \text { in } \\
\text { A549 cells }\end{array}$ & $\begin{array}{l}\text { RASSF } 1 A \text { in } \\
\text { A549 cells }\end{array}$ & ND & 93 \\
\hline \multicolumn{2}{|c|}{18 (laccaic acid) } & 19 & 50 & ND & ND & $\begin{array}{l}V G F \text { and } M A L \\
\text { in MCF7 cells }\end{array}$ & $\begin{array}{c}\text { DNA } \\
\text { competitor }\end{array}$ & 65 \\
\hline \multicolumn{2}{|c|}{19 (SW155246) } & 12 & 38 & ND & $\begin{array}{c}\text { Weak } \\
\text { demethylation at } \\
R A S S F 1 A \\
\text { promoter in A549 } \\
\text { cells }\end{array}$ & $\begin{array}{l}\text { RASSF } 1 A \text { in } \\
\text { A549 cells }\end{array}$ & ND & 67 \\
\hline
\end{tabular}

${ }^{a}$ the $\mathrm{IC}_{50}$ value is reported for the most active compounds; the test conditions are not homogenous ${ }^{\cdot}$

b $\mathrm{TSG}=$ tumor suppressor gene

${ }^{\mathrm{c}} \mathrm{NA}=$ Not Applicable

${ }^{\mathrm{d}} \mathrm{ND}=$ Not Described

e Dnmt3A/3LLcomplex

${ }^{\mathrm{f}}$ controversial results 


\section{AUTHOR INFORMATION}

Corresponding Author

*Paola B. Arimondo, CNRS-Pierre Fabre USR 3388, ETaC, email: paola.arimondo@etac.cnrs.fr

\section{Author Contributions}

The manuscript was written with contributions from all of the authors.

Biographical sketch:

Alexandre Erdmann is a Ph.D. student in Medicinal Chemistry in the ETaC laboratory and will defend his thesis in 2014.

Ludovic Halby is an Engineer in Chemistry at CNRS. His main research interest is developing small molecules that modulate gene expression. He defended a Ph.D. thesis in 2013, which was dedicated to the identification of new inhibitors of DNA methylation.

Jacques Fahy is a senior Scientist in Medicinal Chemistry at Pierre Fabre Laboratories, involved in the discovery of new anti-cancer agents starting mainly from natural products. He joined ETaC in 2011.

Paola B. Arimondo is Research Director at CNRS and head of the ETaC, the CNRS-Pierre Fabre laboratory, since 2011. Her research is situated at the interface of chemistry and biology, with potential applications both in biology (BioChem) and in drug discovery (MedChem).

Funding Sources

Région Midi Pyrenées (Equipe d'Excellence and FEDER), CNRS (ATIP, Equipe d'Excellence and FEDER), Fondation InnaBioSanté. 


\title{
ACKNOWLEDGMENT
}

The authors are grateful to all the past and present members of the ETaC laboratory and to their collaborators, with whom they share the quest for new inhibitors of DNA methyltransferases.

\begin{abstract}
ABBREVIATIONS
DNMT, DNA methyltransferase; DNMTi, DNMT inhibitor; SAM, S-adenosyl-L-methionine; SAH, S-adenosyl-L-homocysteine; HTS, high-throughput screening; HMT, histone methyltransferase; PKMT, protein lysine methyltransferase; HDACi, histone deactetylase inhibitor; PRMT, protein arginine methyltransferase; ROS, reactive oxygen species.
\end{abstract}




\section{REFERENCES}

(1). Bird, A. Perceptions of epigenetics. Nature 2007, 447, 396-398.

(2). Berger, S. L.; Kouzarides, T.; Shiekhattar, R.; Shilatifard, A. An operational definition of epigenetics. Genes Dev. 2009, 23, 781-783.

(3). Feinberg, A. P. Phenotypic plasticity and the epigenetics of human disease. Nature 2007, $447,433-440$.

(4). Portela, A.; Esteller, M. Epigenetic modifications and human disease. Nat. Biotechnol. 2010, 28, 1057-1068.

(5). Esteller, M. Epigenetics in cancer. N. Engl. J. Med. 2008, 358, 1148-1159.

(6). Baylin, S. B.; Jones, P. A. A decade of exploring the cancer epigenome - biological and translational implications. Nat. Rev. Cancer 2011, 11, 726-734.

(7). You, J.S.; Jones, P. A. Cancer genetics and epigenetics: two sides of the same coin? Cancer Cell 2012, 22, 9-20.

(8). Boumber, Y.; Issa, J. P. Epigenetics in cancer: what's the future? Oncology (Williston Park) 2011, 25, 220-226, 228.

(9). Dawson, M. A.; Kouzarides, T. Cancer epigenetics: from mechanism to therapy. Cell 2012, $150,12-27$.

(10). Azad, N.; Zahnow, C. A.; Rudin, C. M.; Baylin, S. B. The future of epigenetic therapy in solid tumours--lessons from the past. Nat. Rev. Clin. Oncol. 2013, 10, 256-266.

(11). Knapp, S.; Weinmann, H. Small-molecule modulators for epigenetics targets. ChemMedChem 2013, 8, 1885-1891. 
(12). Wee, S.; Dhanak, D.; Li, H.; Armstrong, S. A.; Copeland, R. A.; Sims, R.; Baylin, S. B.; Liu, X. S.; Schweizer, L. Targeting epigenetic regulators for cancer therapy. Ann. N. Y. Acad.Sci. 2014, 1309, 30-36.

(13). Copeland, R. A.; Moyer, M. P.; Richon, V. M. Targeting genetic alterations in protein methyltransferases for personalized cancer therapeutics. Oncogene 2013, 32, 939-946.

(14). Reik, W. Stability and flexibility of epigenetic gene regulation in mammalian development. Nature 2007, 447, 425-432.

(15). Jurkowska, R. Z.; Jurkowski, T. P.; Jeltsch, A. Structure and function of mammalian DNA methyltransferases. ChemBiochem 2011, 12, 206-222.

(16). Kim, G. D.; Ni, J.; Kelesoglu, N.; Roberts, R. J.; Pradhan, S. Co-operation and communication between the human maintenance and de novo DNA (cytosine-5) methyltransferases. EMBO J 2002, 21, 4183-4195.

(17). Jia, D.; Jurkowska, R. Z.; Zhang, X.; Jeltsch, A.; Cheng, X. Structure of Dnmt3a bound to Dnmt3L suggests a model for de novo DNA methylation. Nature 2007, 449, 248-251.

(18). Illingworth, R. S.; Bird, A. P. CpG islands--'a rough guide'. FEBS Lett. 2009, 583, 17131720.

(19). Weber, M.; Hellmann, I.; Stadler, M. B.; Ramos, L.; Paabo, S.; Rebhan, M.; Schubeler, D. Distribution, silencing potential and evolutionary impact of promoter DNA methylation in the human genome. Nat. Genet. 2007, 39, 457-466.

(20). Gros, C.; Fahy, J.; Halby, L.; Dufau, I.; Erdmann, A.; Gregoire, J. M.; Ausseil, F.; Vispe, S.; Arimondo, P. B. DNA methylation inhibitors in cancer: recent and future approaches. Biochimie 2012, 94, 2280-2296. 
(21). Auclair, G.; Weber, M. Mechanisms of DNA methylation and demethylation in mammals. Biochimie 2012.

(22). Fournier, A.; Sasai, N.; Nakao, M.; Defossez, P. A. The role of methyl-binding proteins in chromatin organization and epigenome maintenance. Brief Funct. Genomics 2012, 11, 251-264.

(23). Sharma, S.; Kelly, T. K.; Jones, P. A. Epigenetics in cancer. Carcinogenesis 2010, 31, 2736.

(24). Fahy, J.; Jeltsch, A.; Arimondo, P. B. DNA methyltransferase inhibitors in cancer: a chemical and therapeutic patent overview and selected clinical studies. Expert Opin. Ther. Pat. 2012, 22, 1427-1442.

(25). Subramaniam, D.; Thombre, R.; Dhar, A.; Anant, S. DNA methyltransferases: a novel target for prevention and therapy. Front. Oncol. 2014, 4, 80.

(26). Juergens, R. A.; Wrangle, J.; Vendetti, F. P.; Murphy, S. C.; Zhao, M.; Coleman, B.; Sebree, R.; Rodgers, K.; Hooker, C. M.; Franco, N.; Lee, B.; Tsai, S.; Delgado, I. E.; Rudek, M. A.; Belinsky, S. A.; Herman, J. G.; Baylin, S. B.; Brock, M. V.; Rudin, C. M. Combination epigenetic therapy has efficacy in patients with refractory advanced non-small cell lung cancer. Cancer Discov. 2011, 1, 598-607.

(27). Clozel, T.; Yang, S.; Elstrom, R. L.; Tam, W.; Martin, P.; Kormaksson, M.; Banerjee, S.; Vasanthakumar, A.; Culjkovic, B.; Scott, D. W.; Wyman, S.; Leser, M.; Shaknovich, R.; Chadburn, A.; Tabbo, F.; Godley, L. A.; Gascoyne, R. D.; Borden, K. L.; Inghirami, G.; Leonard, J. P.; Melnick, A.; Cerchietti, L. Mechanism-based epigenetic chemosensitization therapy of diffuse large B-cell lymphoma. Cancer Discov. 2013, 3, 1002-1019.

(28). Santi, D. V.; Garrett, C. E.; Barr, P. J. On the mechanism of inhibition of DNA-cytosine methyltransferases by cytosine analogs. Cell 1983, 33, 9-10. 
(29). Santi, D. V.; Norment, A.; Garrett, C. E. Covalent bond formation between a DNAcytosine methyltransferase and DNA containing 5-azacytosine. Proc. Natl. Acad. Sci. U. S. A. 1984, 81, 6993-6997.

(30). Gabbara, S.; Bhagwat, A. S. The mechanism of inhibition of DNA (cytosine-5-)methyltransferases by 5-azacytosine is likely to involve methyl transfer to the inhibitor. Biochem. J. 1995, 307 ( Pt 1), 87-92.

(31). Stresemann, C.; Lyko, F. Modes of action of the DNA methyltransferase inhibitors azacytidine and decitabine. Int. J. Cancer 2008, 123, 8-13.

(32). Issa, J. P.; Kantarjian, H. M. Targeting DNA methylation. Clin. Cancer Res. 2009, 15, 3938-3946.

(33). Derissen, E. J.; Beijnen, J. H.; Schellens, J. H. Concise drug review: azacitidine and decitabine. Oncologist 2013, 18, 619-624.

(34). Marcucci, G.; Silverman, L.; Eller, M.; Lintz, L.; Beach, C. L. Bioavailability of azacitidine subcutaneous versus intravenous in patients with the myelodysplastic syndromes. J. Clin. Pharmacol. 2005, 45, 597-602.

(35). Karahoca, M.; Momparler, R. L. Pharmacokinetic and pharmacodynamic analysis of 5aza-2'-deoxycytidine (decitabine) in the design of its dose-schedule for cancer therapy. Clin. Epigenetics 2013, 5, 3 .

(36). Cheng, J. C.; Matsen, C. B.; Gonzales, F. A.; Ye, W.; Greer, S.; Marquez, V. E.; Jones, P. A.; Selker, E. U. Inhibition of DNA methylation and reactivation of silenced genes by zebularine. J. Natl. Cancer Inst. 2003, 95, 399-409.

(37). Flotho, C.; Claus, R.; Batz, C.; Schneider, M.; Sandrock, I.; Ihde, S.; Plass, C.; Niemeyer, C. M.; Lubbert, M. The DNA methyltransferase inhibitors azacitidine, decitabine and zebularine 
exert differential effects on cancer gene expression in acute myeloid leukemia cells. Leukemia 2009, 23, 1019-1028.

(38). Champion, C.; Guianvarc'h, D.; Senamaud-Beaufort, C.; Jurkowska, R. Z.; Jeltsch, A.; Ponger, L.; Arimondo, P. B.; Guieysse-Peugeot, A. L. Mechanistic insights on the inhibition of c5 DNA methyltransferases by zebularine. PLoS One 2010, 5, e12388.

(39). van Bemmel, D. M.; Brank, A. S.; Eritja, R.; Marquez, V. E.; Christman, J. K. DNA (Cytosine-C5) methyltransferase inhibition by oligodeoxyribonucleotides containing 2-(1H)pyrimidinone (zebularine aglycon) at the enzymatic target site. Biochem. Pharmacol. 2009, 78, 633-641.

(40). Yoo, C. B.; Jeong, S.; Egger, G.; Liang, G.; Phiasivongsa, P.; Tang, C.; Redkar, S.; Jones, P. A. Delivery of 5-aza-2'-deoxycytidine to cells using oligodeoxynucleotides. Cancer Res. 2007, 67, 6400-6408.

(41). Chuang, J. C.; Warner, S. L.; Vollmer, D.; Vankayalapati, H.; Redkar, S.; Bearss, D. J.; Qiu, X.; Yoo, C. B.; Jones, P. A. S110, a 5-Aza-2'-deoxycytidine-containing dinucleotide, is an effective DNA methylation inhibitor in vivo and can reduce tumor growth. Mol. Cancer Ther. 2010, $9,1443-1450$.

(42). Garcia-Manero, G.; Gore, S. D.; Cogle, C.; Ward, R.; Shi, T.; Macbeth, K. J.; Laille, E.; Giordano, H.; Sakoian, S.; Jabbour, E.; Kantarjian, H.; Skikne, B. Phase I study of oral azacitidine in myelodysplastic syndromes, chronic myelomonocytic leukemia, and acute myeloid leukemia. J. Clin. Oncol. 2011, 29, 2521-2527.

(43). Laille, E.; Savona, M. R.; Scott, B. L.; Boyd, T. E.; Dong, Q.; Skikne, B. Pharmacokinetics of different formulations of oral azacitidine (CC-486) and the effect of food and modified gastric 
pH on pharmacokinetics in subjects with hematologic malignancies. J. Clin. Pharmacol. 2014, 54, 630-639.

(44). Ferraris, D.; Duvall, B.; Delahanty, G.; Mistry, B.; Alt, J.; Rojas, C.; Rowbottom, C.; Sanders, K.; Schuck, E.; Huang, K. C.; Redkar, S.; Slusher, B. B.; Tsukamoto, T. Design, synthesis, and pharmacological evaluation of fluorinated tetrahydrouridine derivatives as inhibitors of cytidine deaminase. J.Med. Chem. 2014, 57, 2582-2588.

(45). Christman, J. K. 5-Azacytidine and 5-aza-2'-deoxycytidine as inhibitors of DNA methylation: mechanistic studies and their implications for cancer therapy. Oncogene 2002, 21, 5483-5495.

(46). Datta, J.; Ghoshal, K.; Denny, W. A.; Gamage, S. A.; Brooke, D. G.; Phiasivongsa, P.; Redkar, S.; Jacob, S. T. A new class of quinoline-based DNA hypomethylating agents reactivates tumor suppressor genes by blocking DNA methyltransferase 1 activity and inducing its degradation. Cancer Res. 2009, 69, 4277-4285.

(47). Lee, B. H.; Yegnasubramanian, S.; Lin, X.; Nelson, W. G. Procainamide is a specific inhibitor of DNA methyltransferase 1. J. Biol. Chem. 2005, 280, 40749-40756.

(48). Ceccaldi, A.; Rajavelu, A.; Champion, C.; Rampon, C.; Jurkowska, R.; Jankevicius, G.; Senamaud-Beaufort, C.; Ponger, L.; Gagey, N.; Ali, H. D.; Tost, J.; Vriz, S.; Ros, S.; Dauzonne, D.; Jeltsch, A.; Guianvarc'h, D.; Arimondo, P. B. C5-DNA methyltransferase inhibitors: from screening to effects on zebrafish embryo development. ChemBiochem 2011, 12, 1337-1345.

(49). Xie, Q.; Bai, Q.; Zou, L.-Y.; Zhang, Q.-Y.; Zhou, Y.; Chang, H.; Yi, L.; Zhu, J.-D.; Mi, M.-T. Genistein inhibits DNA methylation and increases expression of tumor suppressor genes in human breast cancer cells. Genes, Chromosomes and Cancer 2014, 53, 422-431. 
(50). Asgatay, S.; Champion, C.; Marloie, G.; Drujon, T.; Senamaud-Beaufort, C.; Ceccaldi, A.; Erdmann, A.; Rajavelu, A.; Schambel, P.; Jeltsch, A.; Lequin, O.; Karoyan, P.; Arimondo, P. B.; Guianvarc'h, D. Synthesis and evaluation of analogues of N-phthaloyl-1-tryptophan (RG108) as inhibitors of DNA methyltransferase 1. J. Med. Chem. 2014, 57, 421-434.

(51). Candelaria, M.; de la Cruz-Hernandez, E.; Taja-Chayeb, L.; Perez-Cardenas, E.; TrejoBecerril, C.; Gonzalez-Fierro, A.; Chavez-Blanco, A.; Soto-Reyes, E.; Dominguez, G.; Trujillo, J. E.; Diaz-Chavez, J.; Duenas-Gonzalez, A. DNA methylation-independent reversion of gemcitabine resistance by hydralazine in cervical cancer cells. PLoS One 2012, 7, e29181.

(52). Rilova, E.; Erdmann, A.; Gros, C.; Masson, V.; Aussagues, Y.; Poughon-Cassabois, V.; Rajavelu, A.; Jeltsch, A.; Menon, Y.; Novosad, N.; Gregoire, J. M.; Vispe, S.; Schambel, P.; Ausseil, F.; Sautel, F.; Arimondo, P. B.; Cantagrel, F. Design, synthesis and biological evaluation of 4-amino-N- (4-aminophenyl)benzamide analogues of quinoline-based SGI-1027 as inhibitors of DNA methylation. ChemMedChem 2014, 9, 590-601.

(53). Gamage, S. A.; Brooke, D. G.; Redkar, S.; Datta, J.; Jacob, S. T.; Denny, W. A. Structureactivity relationships for 4-anilinoquinoline derivatives as inhibitors of the DNA methyltransferase enzyme DNMT1. Bioorg. Med. Chem. 2013, 21, 3147-3153.

(54). Valente, S.; Liu, Y.; Schnekenburger, M.; Zwergel, C.; Cosconati, S.; Gros, C.; Tardugno, M.; Labella, D.; Florean, C.; Minden, S.; Hashimoto, H.; Chang, Y.; Zhang, X.; Kirsch, G.; Novellino, E.; Arimondo, P. B.; Miele, E.; Ferretti, E.; Gulino, A.; Diederich, M.; Cheng, X.; Mai, A. Selective non-nucleoside inhibitors of human DNA methyltransferases active in cancer including in cancer stem cells. J. Med. Chem. 2014, 57, 701-713.

(55). Eglen, R. M.; Reisine, T. Screening for compounds that modulate epigenetic regulation of the transcriptome: an overview. J. Biomol. Screening 2011, 16, 1137-1152. 
(56). Siedlecki, P.; Garcia Boy, R.; Musch, T.; Brueckner, B.; Suhai, S.; Lyko, F.; Zielenkiewicz, P. Discovery of two novel, small-molecule inhibitors of DNA methylation. J. Med.Chem. 2006, 49, 678-683.

(57). Brueckner, B.; Garcia Boy, R.; Siedlecki, P.; Musch, T.; Kliem, H. C.; Zielenkiewicz, P.; Suhai, S.; Wiessler, M.; Lyko, F. Epigenetic reactivation of tumor suppressor genes by a novel small-molecule inhibitor of human DNA methyltransferases. Cancer Res. 2005, 65, 6305-6311.

(58). Stresemann, C.; Brueckner, B.; Musch, T.; Stopper, H.; Lyko, F. Functional diversity of DNA methyltransferase inhibitors in human cancer cell lines. Cancer Res. 2006, 66, 2794-2800.

(59). Suzuki, T.; Tanaka, R.; Hamada, S.; Nakagawa, H.; Miyata, N. Design, synthesis, inhibitory activity, and binding mode study of novel DNA methyltransferase 1 inhibitors. Bioorg. Med. Chem. Lett. 2010, 20, 1124-1127.

(60). Kuck, D.; Singh, N.; Lyko, F.; Medina-Franco, J. L. Novel and selective DNA methyltransferase inhibitors: Docking-based virtual screening and experimental evaluation. Bioorg. Med. Chem. 2010, 18, 822-829.

(61). Kabro, A.; Lachance, H.; Marcoux-Archambault, I.; Perrier, V.; Doré, V.; Gros, C.; Masson, V.; Gregoire, J. M.; Ausseil, F.; Cheishvili, D.; Laulan, N. B.; St-Pierre, Y.; Szyf, M.; Arimondo, P. B.; Gagnon, A. Preparation of phenylethylbenzamide derivatives as modulators of DNMT3 activity. Med. Chem. Commun. 2013, 4, 1562-1570.

(62). Medina-Franco, J. L.; Lopez-Vallejo, F.; Kuck, D.; Lyko, F. Natural products as DNA methyltransferase inhibitors: a computer-aided discovery approach. Mol. Divers. 2011, 15, 293 304. 
(63). Yoo, J.; Medina-Franco, J. L. Towards the chemoinformatic-based identification of DNA methyltransferase inhibitors: 2D- and 3D-similarity profile of screening libraries. Curr. Comput. Aided Drug Des. 2012, 8, 317-329.

(64). Ceccaldi, A.; Rajavelu, A.; Ragozin, S.; Senamaud-Beaufort, C.; Bashtrykov, P.; Testa, N.; Dali-Ali, H.; Maulay-Bailly, C.; Amand, S.; Guianvarc'h, D.; Jeltsch, A.; Arimondo, P. B. Identification of novel inhibitors of DNA methylation by screening of a chemical library. ACS Chem. Biol. 2013, 8, 543-548.

(65). Fagan, R. L.; Cryderman, D. E.; Kopelovich, L.; Wallrath, L. L.; Brenner, C. Laccaic acid A is a direct, DNA-competitive inhibitor of DNA methyltransferase 1. J. Biol. Chem. 2013, 288, 23858-23867.

(66). Fagan, R. L.; Wu, M.; Chedin, F.; Brenner, C. An ultrasensitive high throughput screen for DNA methyltransferase 1-targeted molecular probes. PLoS One 2013, 8, e78752.

(67). Kilgore, J. A.; Du, X.; Melito, L.; Wei, S.; Wang, C.; Chin, H. G.; Posner, B.; Pradhan, S.; Ready, J. M.; Williams, N. S. Identification of DNMT1 selective antagonists using a novel scintillation proximity assay. J. Biol. Chem. 2013, 288, 19673-19684.

(68). Medina-Franco, J. L.; Mendez-Lucio, O.; Yoo, J. Rationalization of activity cliffs of a sulfonamide inhibitor of DNA methyltransferases with induced-fit docking. Int. J. Mol. Sci. 2014, $15,3253-3261$.

(69). Cunningham, S. C.; Ryu, B.; Sohn, T. A.; Kern, S. E. Nonspecific enhancement of gene expression by compounds identified in high-throughput cell-based screening. Biotechniques 2004, $37,120-122$. 
(70). Hossain, M.; Healey, M.; Lee, C.; Poh, W.; Yerram, S.; Patel, K.; Azad, N.; Herman, J.; Kern, S. DNA-intercalators causing rapid re-expression of methylated and silenced genes in cancer cells. OncoTarget 2013, 4, 298-309.

(71). Kubicek, S.; O'Sullivan, R. J.; August, E. M.; Hickey, E. R.; Zhang, Q.; Teodoro, M. L.; Rea, S.; Mechtler, K.; Kowalski, J. A.; Homon, C. A.; Kelly, T. A.; Jenuwein, T. Reversal of H3K9me2 by a small-molecule inhibitor for the G9a histone methyltransferase. Mol. Cell 2007, $25,473-481$.

(72). Vedadi, M.; Barsyte-Lovejoy, D.; Liu, F.; Rival-Gervier, S.; Allali-Hassani, A.; Labrie, V .; Wigle, T. J.; Dimaggio, P. A.; Wasney, G. A.; Siarheyeva, A.; Dong, A.; Tempel, W.; Wang, S. C.; Chen, X.; Chau, I.; Mangano, T. J.; Huang, X. P.; Simpson, C. D.; Pattenden, S. G.; Norris, J. L.; Kireev, D. B.; Tripathy, A.; Edwards, A.; Roth, B. L.; Janzen, W. P.; Garcia, B. A.; Petronis, A.; Ellis, J.; Brown, P. J.; Frye, S. V.; Arrowsmith, C. H.; Jin, J. A chemical probe selectively inhibits G9a and GLP methyltransferase activity in cells. Nat. Chem. Biol. 2011, 7, 566-574.

(73). Liu, F.; Barsyte-Lovejoy, D.; Li, F.; Xiong, Y.; Korboukh, V.; Huang, X. P.; AllaliHassani, A.; Janzen, W. P.; Roth, B. L.; Frye, S. V.; Arrowsmith, C. H.; Brown, P. J.; Vedadi, M.; Jin, J. Discovery of an in vivo chemical probe of the lysine methyltransferases G9a and GLP. J. Med. Chem. 2013, 56, 8931-8942.

(74). Sweis, R. F.; Pliushchev, M.; Brown, P. J.; Guo, J.; Li, F.; Maag, D.; Petros, A. M.; Soni, N. P.; Tse, C.; Vedadi, M.; Michaelides, M. R.; Chiang, G. G.; W.N., P. Discovery and development of potent and selective inhibitors of histone methyltransferase G9a. ACS Med. Chem. Lett. 2014, 5, 205-209.

(75). Qi, W.; Chan, H.; Teng, L.; Li, L.; Chuai, S.; Zhang, R.; Zeng, J.; Li, M.; Fan, H.; Lin, Y.; Gu, J.; Ardayfio, O.; Zhang, J. H.; Yan, X.; Fang, J.; Mi, Y.; Zhang, M.; Zhou, T.; Feng, G.; Chen, 
Z.; Li, G.; Yang, T.; Zhao, K.; Liu, X.; Yu, Z.; Lu, C. X.; Atadja, P.; Li, E. Selective inhibition of Ezh2 by a small molecule inhibitor blocks tumor cells proliferation. Proc. Natl. Acad. Sci. U.S. A. 2012, 109, 21360-21365.

(76). Verma, S. K.; Tian, X.; LaFrance, L. V.; Duquenne, C.; Suarez, D. P.; Newlander, K. A.; Romeril, S. P.; Burgess, J. L.; Grant, S. W.; Brackley, J. A.; Graves, A. P.; Scherzer, D. A.; Shu, A.; Thompson, C.; Ott, H. M.; Van Aller, G. S.; Machutta, C. A.; Diaz, E.; Jiang, Y.; Johnson, N. W.; Knight, S. D.; Kruger, R. G.; McCabe, M. T.; Dhanak, D.; Tummino, P. J.; Creasy, C. L.; Miller, W. H. . Identification of potent, selective, cell-active inhibitors of the histone lysine methyltransferase EZH2. ACS Med. Chem. Lett. 2012, 3, 1091-1096.

(77). Knutson, S. K.; Wigle, T. J.; Warholic, N. M.; Sneeringer, C. J.; Allain, C. J.; Klaus, C. R.; Sacks, J. D.; Raimondi, A.; Majer, C. R.; Song, J.; Scott, M. P.; Jin, L.; Smith, J. J.; Olhava, E. J.; Chesworth, R.; Moyer, M. P.; Richon, V. M.; Copeland, R. A.; Keilhack, H.; Pollock, R. M.; Kuntz, K. W. A selective inhibitor of EZH2 blocks H3K27 methylation and kills mutant lymphoma cells. Nat. Chem. Biol. 2012, 8, 890-896.

(78). Nasveschuk, C. G.; Gagnon, A.; Garapaty-Rao, S.; Balasubramanian, S.; Campbell, R.; Lee, C.; Zhao, F.; Bergeron, L.; Cummings, R.; Trojer, P.; Audia, J. E.; Albrecht, B. K.; Harmange, J. C. Discovery and optimization of tetramethylpiperidinyl benzamides as inhibitors of EZH2. ACS Med. Chem. Lett. 2014, 5, 378-383.

(79). Garapaty-Rao, S.; Nasveschuk, C.; Gagnon, A.; Chan, E. Y.; Sandy, P.; Busby, J.; Balasubramanian, S.; Campbell, R.; Zhao, F.; Bergeron, L.; Audia, J. E.; Albrecht, B. K.; Harmange, J. C.; Cummings, R.; Trojer, P. Identification of EZH2 and EZH1 small molecule inhibitors with selective impact on diffuse large B cell lymphoma cell growth. Chem. Biol. 2013, $20,1329-1339$. 
(80). Diaz, E.; Machutta, C. A.; Chen, S.; Jiang, Y.; Nixon, C.; Hofmann, G.; Key, D.; Sweitzer, S.; Patel, M.; Wu, Z.; Creasy, C. L.; Kruger, R. G.; LaFrance, L.; Verma, S. K.; Pappalardi, M. B.; Le, B.; Van Aller, G. S.; McCabe, M. T.; Tummino, P. J.; Pope, A. J.; Thrall, S. H.; Schwartz, B.; Brandt, M. Development and validation of reagents and assays for EZH2 peptide and nucleosome high-throughput screens. J. Biomol. Screen. 2012, 17, 1279-1292.

(81). Fontan, N.; Garcia-Dominguez, P.; Alvarez, R.; de Lera, A. R. Novel symmetrical ureas as modulators of protein arginine methyltransferases. Bioorg. Med. Chem. 2013, 21, 2056-2067.

(82). Cheng, D.; Yadav, N.; King, R. W.; Swanson, M. S.; Weinstein, E. J.; Bedford, M. T. Small molecule regulators of protein arginine methyltransferases. J. Biol. Chem. 2004, 279, 2389223899.

(83). Wrangle, J.; Wang, W.; Koch, A.; Easwaran, H.; Mohammad, H. P.; Vendetti, F.; Vancriekinge, W.; Demeyer, T.; Du, Z.; Parsana, P.; Rodgers, K.; Yen, R. W.; Zahnow, C. A.; Taube, J. M.; Brahmer, J. R.; Tykodi, S. S.; Easton, K.; Carvajal, R. D.; Jones, P. A.; Laird, P. W.; Weisenberger, D. J.; Tsai, S.; Juergens, R. A.; Topalian, S. L.; Rudin, C. M.; Brock, M. V.; Pardoll, D.; Baylin, S. B. Alterations of immune response of non-smallcell lung cancer with azacytidine. Oncotarget 2013, 4, 2067-2079.

(84). Shlush, L. I.; Zandi, S.; Mitchell, A.; Chen, W. C.; Brandwein, J. M.; Gupta, V.; Kennedy, J. A.; Schimmer, A. D.; Schuh, A. C.; Yee, K. W.; McLeod, J. L.; Doedens, M.; Medeiros, J. J.; Marke, R.; Kim, H. J.; Lee, K.; McPherson, J. D.; Hudson, T. J.; Brown, A. M.; Yousif, F.; Trinh, Q. M.; Stein, L. D.; Minden, M. D.; Wang, J. C.; Dick, J. E. Identification of pre-leukaemic haematopoietic stem cells in acute leukaemia. Nature 2014, 506, 328-333. 
(85). Tang, S.; Liu, X.; Li, T.; Wang, H.; Sun, J.; qiao, Q.; Yao, J.; Fei, J. Comparative analysis of protein expression concomitant with DNA methyltransferase 3A depletion in a melanoma cell line. American Journal of Analytical Chemistry 2011, 2.

(86). Deng, T.; Kuang, Y.; Wang, L.; Li, J.; Wang, Z.; Fei, J. An essential role for DNA methyltransferase 3a in melanoma tumorigenesis. Biochem. Biophys. Res. Commun. 2009, 387, 611-616.

(87). Levitzki, A. Tyrosine kinase inhibitors: views of selectivity, sensitivity, and clinical performance. Annu. Rev. Pharmacol. Toxicol. 2013, 53, 161-185.

(88). Chang, Y.; Zhang, X.; Horton, J. R.; Upadhyay, A. K.; Spannhoff, A.; Liu, J.; Snyder, J. P.; Bedford, M. T.; Cheng, X. Structural basis for G9a-like protein lysine methyltransferase inhibition by BIX-01294. Nat. Struct. Mol. Biol. 2009, 16, 312-317.

(89). Konze, K. D.; Ma, A.; Li, F.; Barsyte-Lovejoy, D.; Parton, T.; Macnevin, C. J.; Liu, F.; Gao, C.; Huang, X. P.; Kuznetsova, E.; Rougie, M.; Jiang, A.; Pattenden, S. G.; Norris, J. L.; James, L. I.; Roth, B. L.; Brown, P. J.; Frye, S. V .; Arrowsmith, C. H.; Hahn, K. M.; Wang, G. G.; Vedadi, M.; Jin, J. An orally bioavailable chemical probe of the lysine methyltransferases EZH2 and EZH1. ACS Chem. Biol. 2013, 8, 1324-1334.

(90). Yao, Y.; Chen, P.; Diao, J.; Cheng, G.; Deng, L.; Anglin, J. L.; Prasad, B. V.; Song, Y. Selective inhibitors of histone methyltransferase DOT1L: design, synthesis, and crystallographic studies. J. Am. Chem. Soc. 2011, 133, 16746-16749.

(91). Umemoto, N.; Ohnuma, T.; Urpilainen, H.; Yamamoto, T.; Numata, T.; Fukamizo, T. Role of tryptophan residues in a class $\mathrm{V}$ chitinase from Nicotiana tabacum. Biosci.Biotechnol.Biochem. 2012, 76, 778-784. 
(92). Isakovic, L.; Saavedra, O. M.; Llewellyn, D. B.; Claridge, S.; Zhan, L.; Bernstein, N.; Vaisburg, A.; Elowe, N.; Petschner, A. J.; Rahil, J.; Beaulieu, N.; Gauthier, F.; MacLeod, A. R.; Delorme, D.; Besterman, J. M.; Wahhab, A. Constrained (1-)-S-adenosyl-1-homocysteine (SAH) analogues as DNA methyltransferase inhibitors. Bioorg. Med. Chem. Lett. 2009, 19, 2742-2746.

(93). Kuck, D.; Caulfield, T.; Lyko, F.; Medina-Franco, J. L. Nanaomycin A selectively inhibits DNMT3B and reactivates silenced tumor suppressor genes in human cancer cells. Mol. Cancer Ther. 2010, 9, 3015-3023.

(94). Jurkowska, R. Z.; Ceccaldi, A.; Zhang, Y.; Arimondo, P. B.; Jeltsch, A. DNA methyltransferase assays. Methods Mol. Biol. 2011, 791, 157-177.

(95). Gros, C.; Chauvigne, L.; Poulet, A.; Menon, Y.; Ausseil, F.; Dufau, I.; Arimondo, P. B. Development of a universal radioactive DNA methyltransferase inhibition test for high-throughput screening and mechanistic studies. Nucleic Acids Res. 2013, 41, e185.

(96). Rotili, D.; Tarantino, D.; Marrocco, B.; Gros, C.; Masson, V.; Poughon, V.; Ausseil, F.; Chang, Y.; Labella, D.; Cosconati, S.; Di Maro, S.; Novellino, E.; Schnekenburger, M.; Grandjenette, C.; Bouvy, C.; Diederich, M.; Cheng, X.; Arimondo, P. B.; Mai, A. Properly substituted analogues of BIX-01294 lose inhibition of G9a histone methyltransferase and gain selective anti-DNA methyltransferase 3A activity. PLoS One 2014, 9, e96941.

(97). Kang, J. S.; Meier, J. L.; Dervan, P. B. Design of sequence-specific DNA binding molecules for DNA methyltransferase inhibition. J. Am. Chem. Soc. 2014, 136, 3687-3694.

(98). Shieh, F. K.; Youngblood, B.; Reich, N. O. The role of Arg165 towards base flipping, base stabilization and catalysis in M.HhaI. J. Mol. Biol. 2006, 362, 516-527.

(99). Hashimoto, H.; Horton, J. R.; Zhang, X.; Bostick, M.; Jacobsen, S. E.; Cheng, X. The SRA domain of UHRF1 flips 5-methylcytosine out of the DNA helix. Nature 2008, 455, 826-829. 
(100). Wahnon, D. C.; Shier, V. K.; Benkovic, S. J. Mechanism-based inhibition of an essential bacterial adenine DNA methyltransferase: rationally designed antibiotics. J. Am. Chem. Soc. 2001, $123,976-977$.

(101). Hashimoto, H.; Vertino, P. M.; Cheng, X. Molecular coupling of DNA methylation and histone methylation. Epigenomics 2010, 2, 657-669.

(102). Rothbart, S. B.; Krajewski, K.; Nady, N.; Tempel, W.; Xue, S.; Badeaux, A. I.; BarsyteLovejoy, D.; Martinez, J. Y.; Bedford, M. T.; Fuchs, S. M.; Arrowsmith, C. H.; Strahl, B. D. Association of UHRF1 with methylated H3K9 directs the maintenance of DNA methylation. Nat. Struct. Mol. Biol. 2012, 19, 1155-1160.

(103). Bashtrykov, P.; Jankevicius, G.; Jurkowska, R. Z.; Ragozin, S.; Jeltsch, A. The UHRF1 protein stimulates the activity and specificity of the maintenance DNA methyltransferase DNMT1 by an allosteric mechanism. J. Biol. Chem. 2014, 289, 4106-4115.

(104). Cheray, M.; Nadaradjane, A.; Bonnet, P.; Routier, S.; Vallette, F. M.; Cartron, P. F. Specific inhibition of DNMT1/CFP1 reduces cancer phenotypes and enhances chemotherapy effectiveness. Epigenomics 2014, 6, 267-275.

(105). Kim, W.; Bird, G. H.; Neff, T.; Guo, G.; Kerenyi, M. A.; Walensky, L. D.; Orkin, S. H. Targeted disruption of the EZH2-EED complex inhibits EZH2-dependent cancer. Nat. Chem. Biol. 2013, 9, 643-650.

(106). Cao, F.; Townsend, E. C.; Karatas, H.; Xu, J.; Li, L.; Lee, S.; Liu, L.; Chen, Y.; Ouillette, P.; Zhu, J.; Hess, J. L.; Atadja, P.; Lei, M.; Qin, Z. S.; Malek, S.; Wang, S.; Dou, Y. Targeting MLL1 H3K4 methyltransferase activity in mixed-lineage leukemia. Mol. Cell 2014, 53, 247-261. (107). Egger, G.; Liang, G.; Aparicio, A.; Jones, P. A. Epigenetics in human disease and prospects for epigenetic therapy. Nature 2004, 429, 457-463. 
(108). Kriaucionis, S.; Heintz, N. The nuclear DNA base 5-hydroxymethylcytosine is present in Purkinje neurons and the brain. Science 2009, 324, 929-930.

(109). Tahiliani, M.; Koh, K. P.; Shen, Y.; Pastor, W. A.; Bandukwala, H.; Brudno, Y.; Agarwal, S.; Iyer, L. M.; Liu, D. R.; Aravind, L.; Rao, A. Conversion of 5-methylcytosine to 5hydroxymethylcytosine in mammalian DNA by MLL partner TET1. Science 2009, 324, 930-935. (110). Franchini, D. M.; Schmitz, K. M.; Petersen-Mahrt, S. K. 5-Methylcytosine DNA demethylation: more than losing a methyl group. Annu. Rev. Genet. 2012, 46, 419-441.

(111). Tsai, H. C.; Li, H.; Van Neste, L.; Cai, Y.; Robert, C.; Rassool, F. V.; Shin, J. J.; Harbom, K. M.; Beaty, R.; Pappou, E.; Harris, J.; Yen, R. W.; Ahuja, N.; Brock, M. V.; Stearns, V.; FellerKopman, D.; Yarmus, L. B.; Lin, Y. C.; Welm, A. L.; Issa, J. P.; Minn, I.; Matsui, W.; Jang, Y. Y.; Sharkis, S. J.; Baylin, S. B.; Zahnow, C. A. Transient low doses of DNA-demethylating agents exert durable antitumor effects on hematological and epithelial tumor cells. Cancer Cell 2012, 21, 430-446.

(112). Rhee, I.; Bachman, K. E.; Park, B. H.; Jair, K. W.; Yen, R. W.; Schuebel, K. E.; Cui, H.; Feinberg, A. P.; Lengauer, C.; Kinzler, K. W.; Baylin, S. B.; Vogelstein, B. DNMT1 and DNMT3b cooperate to silence genes in human cancer cells. Nature 2002, 416, 552-556.

(113). Rhee, I.; Jair, K. W.; Yen, R. W.; Lengauer, C.; Herman, J. G.; Kinzler, K. W.; Vogelstein, B.; Baylin, S. B.; Schuebel, K. E. CpG methylation is maintained in human cancer cells lacking DNMT1. Nature 2000, 404, 1003-1007.

(114). Chik, F.; Szyf, M.; Rabbani, S. A. Role of epigenetics in cancer initiation and progression. Adv. Exp. Med. Biol. 2011, 720, 91-104. 
(115). Chen, T.; Hevi, S.; Gay, F.; Tsujimoto, N.; He, T.; Zhang, B.; Ueda, Y.; Li, E. Complete inactivation of DNMT1 leads to mitotic catastrophe in human cancer cells. Nat. Genet. 2007, 39, 391-396.

(116). Ghoshal, K.; Datta, J.; Majumder, S.; Bai, S.; Kutay, H.; Motiwala, T.; Jacob, S. T. 5-Azadeoxycytidine induces selective degradation of DNA methyltransferase 1 by a proteasomal pathway that requires the KEN box, bromo-adjacent homology domain, and nuclear localization signal. Mol. Cell. Biol. 2005, 25, 4727-4741.

(117). Li, L. H.; Olin, E. J.; Buskirk, H. H.; Reineke, L. M. Cytotoxicity and mode of action of 5azacytidine on L1210 leukemia. Cancer Res. 1970, 30, 2760-2769.

(118). Jones, P. A.; Taylor, S. M. Cellular-differentiation, cytidine analogs and DNA methylation. Cell 1980, 20, 85-93.

(119). Gore, S. D.; Jones, C.; Kirkpatrick, P. Decitabine. Nat. Rev. Drug Discov. 2006, 5, 891892.

(120). Issa, J. P.; Kantarjian, H. Azacitidine. Nat. Rev. Drug Discov. 2005, Suppl, S6-7.

(121). Creusot, F.; Acs, G.; Christman, J. K. Inhibition of DNA methyltransferase and induction of Friend erythroleukemia cell differentiation by 5-azacytidine and 5-aza-2'-deoxycytidine. J. Biol. Chem. 1982, 257, 2041-2048.

(122). Taylor, S. M.; Jones, P. A. Mechanism of action of eukaryotic DNA methyltransferase. Use of 5-azacytosine-containing DNA. J. Mol. Biol. 1982, 162, 679-692.

(123). Jones, P. A. Altering gene expression with 5-azacytidine. Cell 1985, 40, 485-486.

(124). Zhang, Y.; Rohde, C.; Tierling, S.; Jurkowski, T. P.; Bock, C.; Santacruz, D.; Ragozin, S.; Reinhardt, R.; Groth, M.; Walter, J.; Jeltsch, A. DNA methylation analysis of chromosome 21 gene promoters at single base pair and single allele resolution. PLoS Genet. 2009, 5, e1000438. 
(125). Driscoll, J. S.; Marquez, V. E.; Plowman, J.; Liu, P. S.; Kelley, J. A.; Barchi, J. J., Jr. Antitumor properties of 2(1H)-pyrimidinone riboside (zebularine) and its fluorinated analogues. J. Med. Chem. 1991, 34, 3280-3284.

(126). Zhou, L.; Cheng, X.; Connolly, B. A.; Dickman, M. J.; Hurd, P. J.; Hornby, D. P. Zebularine: a novel DNA methylation inhibitor that forms a covalent complex with DNA methyltransferases. J. Mol. Biol. 2002, 321, 591-599.

(127). Marquez, V. E.; Barchi, J. J., Jr.; Kelley, J. A.; Rao, K. V.; Agbaria, R.; Ben-Kasus, T.; Cheng, J. C.; Yoo, C. B.; Jones, P. A. Zebularine: a unique molecule for an epigenetically based strategy in cancer chemotherapy. The magic of its chemistry and biology. Nucleosides Nucleotides Nucleic Acids 2005, 24, 305-318.

(128). Herranz, M.; Martin-Caballero, J.; Fraga, M. F.; Ruiz-Cabello, J.; Flores, J. M.; Desco, M.; Marquez, V.; Esteller, M. The novel DNA methylation inhibitor zebularine is effective against the development of murine T-cell lymphoma. Blood 2006, 107, 1174-1177.

(129). Cheng, J. C.; Weisenberger, D. J.; Gonzales, F. A.; Liang, G.; Xu, G. L.; Hu, Y. G.; Marquez, V. E.; Jones, P. A. Continuous zebularine treatment effectively sustains demethylation in human bladder cancer cells. Mol. Cell. Biol. 2004, 24, 1270-1278.

(130). Cheng, J. C.; Yoo, C. B.; Weisenberger, D. J.; Chuang, J.; Wozniak, C.; Liang, G.; Marquez, V. E.; Greer, S.; Orntoft, T. F.; Thykjaer, T.; Jones, P. A. Preferential response of cancer cells to zebularine. Cancer Cell 2004, 6, 151-158.

(131). Yoo, C. B.; Cheng, J. C.; Jones, P. A. Zebularine: a new drug for epigenetic therapy. Biochem. Soc. Trans. 2004, 32, 910-912.

(132). Castellano, S.; Kuck, D.; Viviano, M.; Yoo, J.; Lopez-Vallejo, F.; Conti, P.; Tamborini, L.; Pinto, A.; Medina-Franco, J. L.; Sbardella, G. Synthesis and biochemical evaluation of delta(2)- 
isoxazoline derivatives as DNA methyltransferase 1 inhibitors. J. Med. Chem. 2011, 54, 76637677.

(133). Halby, L.; Champion, C.; Senamaud-Beaufort, C.; Ajjan, S.; Drujon, T.; Rajavelu, A.; Ceccaldi, A.; Jurkowska, R.; Lequin, O.; Nelson, W. G.; Guy, A.; Jeltsch, A.; Guianvarc'h, D.; Ferroud, C.; Arimondo, P. B. Rapid synthesis of new DNMT inhibitors derivatives of procainamide. ChemBiochem 2012, 13, 157-165.

(134). Yoo, J.; Choi, S.; Medina-Franco, J. L. Molecular modeling studies of the novel inhibitors of DNA methyltransferases SGI-1027 and CBC12: implications for the mechanism of inhibition of DNMTs. PLoS One 2013, 8, e62152.

(135). Castellano, S.; Kuck, D.; Sala, M.; Novellino, E.; Lyko, F.; Sbardella, G. Constrained analogues of procaine as novel small molecule inhibitors of DNA methyltransferase-1. J. Med. Chem. 2008, 51, 2321-2325.

(136). Fang, M. Z.; Chen, D.; Sun, Y.; Jin, Z.; Christman, J. K.; Yang, C. S. Reversal of hypermethylation and reactivation of p16INK4a, RARbeta, and MGMT genes by genistein and other isoflavones from soy. Clin. Cancer Res. 2005, 11, 7033-7041.

(137). Lee, W. J.; Shim, J. Y.; Zhu, B. T. Mechanisms for the inhibition of DNA methyltransferases by tea catechins and bioflavonoids. Mol. Pharmacol. 2005, 68, 1018-1030. (138). Nandakumar, V.; Vaid, M.; Katiyar, S. K. (-)-Epigallocatechin-3-gallate reactivates silenced tumor suppressor genes, Cip1/p21 and p16INK4a, by reducing DNA methylation and increasing histones acetylation in human skin cancer cells. Carcinogenesis 2011, 32, 537-544.

(139). Mirza, S.; Sharma, G.; Parshad, R.; Gupta, S. D.; Pandya, P.; Ralhan, R. Expression of DNA methyltransferases in breast cancer patients and to analyze the effect of natural compounds on DNA methyltransferases and associated proteins. J. Breast Cancer 2013, 16, 23-31. 
(140). Graca, I.; Sousa, E. J.; Baptista, T.; Almeida, M.; Ramalho-Carvalho, J.; Palmeira, C.; Henrique, R.; Jeronimo, C. Anti-tumoral effect of the non-nucleoside DNMT inhibitor RG108 in human prostate cancer cells. Curr. Pharm. Des. 2014, 20, 1803-1811.

(141). Savickiene, J.; Treigyte, G.; Borutinskaite, V. V .; Navakauskiene, R. Antileukemic activity of combined epigenetic agents, DNMT inhibitors zebularine and RG108 with HDAC inhibitors, against promyelocytic leukemia HL-60 cells. Cell. Mol. Biol. Lett. 2012, 17, 501-525.

(142). Brueckner, B.; Boy, R. G.; Siedlecki,P.; Musch, T.; Kliem, H. C.; Zielenkiewicz, P.; Suhai, S.; Wiessler, M.; Lyko, F. Epigenetic reactivation of tumor suppressor genes by a novel smallmolecule inhibitor of human DNA methyltransferases. Cancer Res. 2005, 65, 6305-6311. 